\title{
Development of a Highly Active Fluorescence-Based Detector for Yeast G Protein-Coupled Receptor Ste2p ${ }^{\text {[S }}$
}

\author{
Jin Woo Hong ${ }^{1}$, Hee Jun Ahn ${ }^{1 \dagger}$, Jee Su Baek ${ }^{1 \dagger}$, Eun young Hong ${ }^{1}$, Dong Hoon Jin ${ }^{2}$, Yong Ho Khang ${ }^{1}$, and \\ Nam Joo Hong ${ }^{1 *}$ \\ ${ }^{1}$ School of Biotechnology, Yeungnam University, Gyeongsan 38541, Republic of Korea \\ ${ }^{2}$ Asan Institute for Life Science, Department of Convergence Medicine, College of Medicine, University of Ulsan 44610, Republic of Korea
}

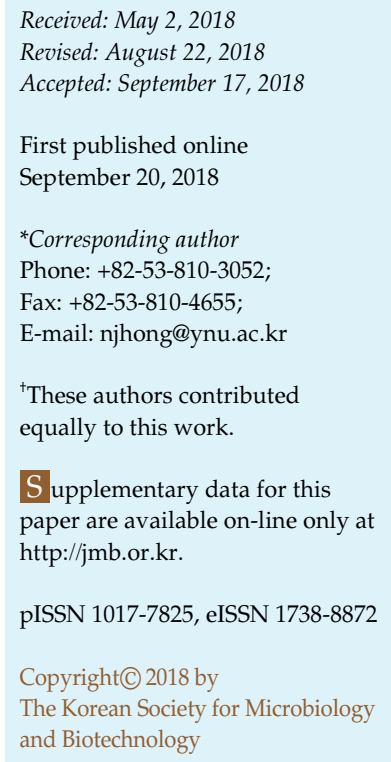

Twenty analogs of $\left[\mathrm{Orn}^{6}, \mathrm{D}-\mathrm{Ala}^{9}\right] \alpha$-factor were synthesized and assayed for their biological activities: seven analogs of $\left[\mathrm{Orn}^{6}, \mathrm{X}^{9}\right] \alpha$-factor, seven analogs of $\left[\mathrm{X}^{6}, \mathrm{D}-\mathrm{Ala}{ }^{9}\right] \alpha$-factor, five analogs of $\left[X^{5}, X^{6}, D-A l a^{9}\right] \alpha$-factor, and native $\alpha$-factor ( $X=$ amino acids). Their biological activities (halo, gene induction, and affinity) were measured using S. cerevisiae Y7925 and LM102 and compared with those of native $\alpha$-factor $(100 \%)$. G protein-coupled receptor was expressed in strain LM102 containing pESC-LEU-STE2 vector. [ Dap $\left.^{6}, \mathrm{D}-\mathrm{Ala}^{9}\right] \alpha$-factor with weak halo activity $(10 \%)$ showed the highest receptor affinity $(>230 \%)$ and the highest gene induction activity $(167 \%)$. $\left[\mathrm{Arg}^{6}, \mathrm{D}-\mathrm{Ala}{ }^{9}\right] \alpha$-factor showed the highest halo activity $(2,000 \%)$. The number of active binding sites per cell (about 20,000 for strain LM102) was determined using a newlydesigned fluorescence-based detector, $\left[\mathrm{Arg}^{6}{ }^{6} \mathrm{D}-\mathrm{Ala}^{9}\right] \alpha$-factor-Edan, with high sensitivity $\left(12,500\right.$-fold higher than the absorption-based detector [Orn $\left.{ }^{6}\right] \alpha$-factor-[Cys $\left.]_{3}\right)$.

Keywords: $\alpha$-Factor, fluorescence detector, affinity, LM102

\section{Introduction}

The discovery of peptides possessing high biological activities is very challenging since only a minority will have the desired properties. To avoid any side effects, a valuable peptide drug precursor must have high affinity for the target protein while minimizing interactions with other proteins. Unfortunately, only a few peptides have been shown to possess such properties, and these must be identified from an enormous number of candidate compounds. This combinatorial search problem is very challenging, and other factors such as bioavailability and stability have to be considered as well.

The native $\alpha$-factor, tridecapeptide (WHWLQLKPGQPMY), is secreted by Saccharomyces cerevisiae MAT haploid cells and recognized by a receptor coded by the STE2 gene, which is expressed in $S$. cerevisiae MATa haploid cells [1]. The $\alpha$-factor pheromone receptor (Ste2p) belongs to the large family of G protein-coupled receptors (GPCRs) [2-4], which are involved in the control of many aspects of metabolism and drive processes associated with pain perception, growth and blood pressure regulation, and viral pathogenesis [2]. Thus, understanding the structurefunction relationships of these proteins is important for GPCR-based drug discovery. Specifically, yeast Ste2p has been studied as a model of peptide-responsive GPCRs, as it has several advantages over other systems such as low growth and maintenance costs as well as easy recombination and expression of mutant versions of receptors [3].

The yeast $S$. cerevisiae tridecapeptide pheromone native $\alpha$-factor has been studied as a model for exploring the structure-function relationships of this important class of GPCR ever since it was first isolated over three decades ago [5]. Although hundreds of $\alpha$-factor analogs have been reported [4, 6-9], most synthetic analogs reported to date are far less active than native $\alpha$-factor, and only a few are 
as active as $\alpha$-factor $[4,6,7]$. Surprisingly, none of these analogs exceeds 3- to 4-fold halo activity compared to native $\alpha$-factor $[4,6]$. [D-Ala $\left.{ }^{9}, \mathrm{Nle}^{12}\right] \alpha$-factor is the most active analog, having about 5 -fold higher activity than its parent analog, $\left[\mathrm{Nle}^{12}\right] \alpha$-factor $[10,11]$.

A recently reported analog, [Orn $\left.{ }^{6}\right] \alpha$-factor, exceeded 5fold halo activity, exhibiting 7.0-fold higher activity in the halo assay and 1.8-fold higher receptor affinity compared to the native $\alpha$-factor. Based on this result, two additional double-substituted analogs, $\left[\mathrm{Glu}^{6}, \mathrm{D}-\mathrm{Ala}^{9}\right] \alpha$-factor and $\left[\mathrm{Orn}^{6}, \mathrm{D}\right.$ $\left.\mathrm{Ala}^{9}\right] \alpha$-factor, were also reported. [12] The former substituted with a negatively-charged residue exhibited slightly decreased halo activity and receptor affinity compared to [Orn $\left.{ }^{6}\right] \alpha$-factor, whereas the latter substituted with a positively-charged residue showed nearly 15 -fold increased halo activity as well as 3 -fold increased affinity compared to native $\alpha$-factor.

In this study, to enhance the biological activity of native $\alpha$-factor based on $\left[\mathrm{Orn}^{6}{ }^{6} \mathrm{D}-\mathrm{Ala}^{9}\right] \alpha$-factor, which has high biological activity as well as high receptor affinity, we designed a series of $\left[\mathrm{Orn}^{6}, \mathrm{D}-\mathrm{Ala}^{9}\right] \alpha$-factor analogs in which D-Ala ${ }^{9}$ was substituted with other D-amino acid residues. Furthermore, the three-carbon aliphatic side chain of Orn ${ }^{6}$ was adjusted in order to vary carbon numbers of aliphatic side chains from one to four by substituting other positively charged residues such as diaminopropionic acid (Dap), diaminobutyric acid (Dab), and Lys. Arg or N-methyl Arg was also incorporated into position 6 instead of Orn to alter the amino group of the Orn $^{6}$ side chain to a guanidinium group. Such designs are expected to afford more detailed information about the binding environment of the position 6 side chain. Based on the results, we extended our investigation to position 5, in which Gln was substituted with other residues such as Orn, Asp, Ser, and Ala.

In our previous study, [13] we reported ligand-binding assays for GPCRs from yeast whole cells based on spectrophotometric measurement using a tri-cysteine detector. The method was demonstrated to be rapid and convenient for measuring the receptor affinities of $\alpha$-factors, but its major drawback was a low sensitivity requiring high concentrations of both cells and detector. Therefore, a more sensitive method for the accurate measurement of $\alpha$-factor binding to its cognate receptors on cells is needed. Thus, we developed a fluorescence-based detector and analyzed its performance by comparing with absorption-based assay to determine the analytical efficacies of ligand-binding for GPCRs from yeast whole cells. A tri-cysteine detector containing three cysteines at its C-terminus was used for spectrophotometric measurement, whereas fluorometric measurement employed the newly developed detector
$\left[\mathrm{Arg}^{6}, \mathrm{D}-\mathrm{Ala}^{9}\right] \alpha$-factor-Edan [Edan = 5-((2-aminoethyl)amino) naphthalene-1-sulfonic acid], which has a fluorophore at its C-terminus. Both methods were shown to be completely satisfactory and efficient for measuring the receptor affinities of all nonchromogenic analogs. The relative affinities of synthetic analogs against Ste2p were easily determined by measuring their effects on binding to cognate receptor and characterized in terms of equilibrium dissociation constant $\left(K_{D}\right)$. The $K_{D}$ values were determined using two cognate GPCRs of S. cerevisiae MATa, Y7925 and LM102. Strain LM102, a mutant deficient in STE2 gene, is incapable of producing $\alpha$-factor receptor. [14] Thus, we constructed vector pESC-LEU-STE2 by cloning STE2 fragment into plasmid pESC-LEU $[15,16]$ to produce GPCR with strain LM102. Vector pESC-LEU-STE2 was transformed into competent recipient LM102 cells following plasmid production using Escherichia coli DH5 $\alpha$. Therefore, we clearly assessed the expression of Ste2p in S. cerevisiae LM102 by gene induction assay and saturation binding assay using our newly developed fluorescence-based detector.

\section{Materials and Methods}

\section{Synthesis of $\alpha$-Factor Analogs}

All $\alpha$-factor analogs were prepared using a solid-phase strategy. The procedure followed the synthetic protocol previously described by Hong $[17,18]$. Target peptides were analyzed by reversed-phase, high-performance liquid chromatography (Shimazdu Prominence HPLC) on an analytical Vydac Everest C18 reversedphase polymer column with detection at $220 \mathrm{~nm}$. Fractions displaying over $97 \%$ homogeneity were pooled and subjected to lyophilization. Molecular weights of the final peptides were assessed by LC/MS (Agilent HP1100 series) (Table S1 and Fig. S1).

\section{Organisms}

Strains S. cerevisiae Y7925 [MATa his3-532 trp1 gal2] and E. coli DH5 $\alpha$ [fhuA2 lac(del)U169 phoA glnV44 Ф80' lacZ(del)M15 gyrA96 recA1 relA1 endA1 thi-1 hsdR17] were purchased from the Korean Collection. Strain S. cerevisiae LM102 [MATa, bar1, leu2, ura3, FUS1-lacZ:URA3, STE2-dl] was kindly provided by Prof. J. M. Becker at the University of Tennessee. Strains were maintained and grown on YEPD medium (yeast extract: $1 \%$, peptone: $2 \%$, dextrose: $2 \%$ ) at $30^{\circ} \mathrm{C}$. Both strains were selected as test organisms for growth arrest, halo, and receptor affinity assays of synthetic $\alpha$-factor analogs reported in this paper.

\section{Plasmid Construction}

Plasmid pESC-LEU, which was used for the in vitro transcription and translation of STE2, was constructed by inserting the $2 \mathrm{~kb}$ of STE2 into the MCS2/myc site. Wild-type GPCR cDNA was amplified by PCR using the forward primer seq-F (CTTTCAACA 
TTTTCGGTTTG) and the reverse primer seq-R (CGTCTGTACAGA $A A A A A A A G)$. The seq-F primer was located at the 107 base upstream of the start codon (ATG) of the STE2 gene and the seq-R primer was located at the 148 base downstream of the His tag of STE2 gene. PCR was performed in the presence of $1.25 \mathrm{U}$ of Taq DNA polymerase (Invitrogen Life Tech.), $2 \times$ PCR $\times$ enhancer solution, $0.3 \mathrm{mmol} / 1$ of each dNTP, $1 \mathrm{mmol} / 1$ of $\mathrm{MgSO}_{4}$, and $0.3 \mu \mathrm{mol} / 1$ of each primer. PCR consisted of 30 cycles of $45 \mathrm{sec}$ at $94^{\circ} \mathrm{C}, 45 \mathrm{sec}$ at $55^{\circ} \mathrm{C}, 2.5 \mathrm{~min}$ at $68^{\circ} \mathrm{C}$, and $5 \mathrm{~min}$ at $68^{\circ} \mathrm{C}$. The amplified fragments were then purified (PCR purification kit: Qiagen SA, Couraboeuf, France). The final product was digested with the restriction endonucleases, BamH1 and HindIII, and cloned into the same site of the plasmid pESC-LEU [15]. His6 tag sequence functioning as an affinity tag was added at the $3^{\prime}$ end site of the STE2 gene. The GAL1 promoter, which regulates the transcription of the STE2 gene encoding Ste2p, was placed upstream of the MCS2/myc site (Fig. S2) [19].

\section{pESC-LEU-STE2 Transformation for Plasmid Production and} Plasmid Extraction

Manipulations were performed as described in standard protocol [20]. E. coli $\mathrm{DH} 5 \alpha$ competent cells were used to amplify pESC-LEU-STE2. Plasmid was transformed into E. coli DH5 $\alpha$ competent cells by heat-shock at $42^{\circ} \mathrm{C}$. The transformed cells were grown in LB broth-containing ampicillin. SP2 solution $(0.2 \mathrm{~N}$ $\mathrm{NaOH}, 1 \%$ SDS) was used for cell lysis. Plasmid extracts were separated by spin column.

\section{Yeast Transformation with Shuttle Vector pESC-LEU-STE2}

Manipulations were performed as described in the standard protocol. [16] The vector pESC-LEU-STE2 was introduced into yeast LM102 cells using denatured salmon sperm carrier DNA by heat-shock at $42^{\circ} \mathrm{C}$. The cell suspensions were spread onto Synthetic Defined Dropout Media [16]. The transformants appeared after 3 days at $30^{\circ} \mathrm{C}$ and the complete number of transformants was recorded after 5 days.

\section{DNA Electrophoresis with STE2 Gene}

The procedure was conducted according to standard procedures using a sample pretreated with the restriction enzymes, BamH1 and HindIII [21]. A standard DNA-sequencing gel apparatus (Mupid, Tokyo, Japan) was used with $52 \times 60 \mathrm{~mm}$ plates. The gel on the plate was stained with ethidium bromide (Fig. S3).

SDS Gel Electrophoresis with GPCR and Western Blot Analysis

Transformed LM102 cells were washed with ice-cold distilled water and lysed with a glass bead-containing protease inhibitor cocktail (Sigma-Aldrich, USA). Subsequent to protein isolation and concentration determination, proteins (100 ng) were electrophoresed on an $8 \%$ SDS-polyacrylamide gel and transferred to a PVDF membrane (Millipore, USA). The blots were then blocked with 3\% bovine serum albumin (BSA) in Tris-buffered saline (TBS)-Tween
20 for $1 \mathrm{~h}$, incubated overnight with 6-His Antibody (Bethyl Laboratories, USA), and diluted with $1 \%$ BSA in TBS at $4^{\circ} \mathrm{C}$. After they were washed, the blots were incubated with horseradish peroxidase (HRP)-conjugated secondary antibody (Santa Cruz Biotechnology, USA) for $1 \mathrm{~h}$ at room temperature and developed with Pierce ECL Western Blotting Substrate (Thermo Fisher Scientific Life Sciences, USA). The protein isolated using an NiNTA affinity column (HisTrap excel, GE Healthcare, Sweden) was used for SDS gel electrophoresis according to standard procedures using a BioRad electrophoresis apparatus (Tetra Cell, BioRad, China) connected to an EPS 400/500 (BioRad, Singapore) power supply (Fig. S4) [22].

\section{FUS1-lacZ Gene Induction Assay Using Strain LM102}

Assays of FUS1-lacZ gene induction in response to pheromone were performed as previously described, except digitonin was used for the rapid permeabilization of yeast cells [23]. $\beta$-Galactosidase production assays using various analogs were performed by adding $1 \mu \mathrm{l}$ of fluorescein-containing $\beta$-D-galactopyranoside (FDG) solution $(1 \mathrm{mM})$ to $950 \mu \mathrm{l}$ of supernatant, in which distilled water was added to a final volume of $1 \mathrm{ml}$ [24]. Fluorescence was measured using a cuvette cell reader (Fluorophotometer LS55, PerkinElmer, USA) at an excitation wavelength of $460 \mathrm{~nm}$ and an emission wavelength of $520 \mathrm{~nm}$. Data were plotted and analyzed to determine $\beta$-galactosidase induction according to the analog concentration (Fig. 1) [23].

\section{Standard Curve for FDG and $\left[\mathrm{Arg}^{6}{ }^{6} \mathrm{D}-\mathrm{Ala}{ }^{9}\right] \alpha$-Factor-Edan}

The procedures followed general procedures or the manufacturers' instructions [25]. Fluorescence of each FDG solution (0, 0.05, 0.1, $0.2,0.3,0.4,0.5,0.7,1$, and $1.5 \mu \mathrm{l}$ ) excited at a wavelength of 489 $\mathrm{nm}$ was monitored at an emission wavelength of $520 \mathrm{~nm}$. On the other hand, fluorescence of Edan detector $(0,0.05,0.1,0.2,0.3,0.4$, $0.5,0.7,1$, and $1.5 \mu \mathrm{l})$ excited at a wavelength of $430 \mathrm{~nm}$ was monitored at an emission wavelength of $510 \mathrm{~nm}$ (Figs. S6 and S7).

Steady-State Saturation Binding with Absorption-Based Detector [Orn $\left.{ }^{6}\right] \alpha-F a c t o r-[C y s]_{3}$ (Fig. S9)

The procedure followed the assay protocol previously described by Hong [13]. Steady-state saturation binding for Scatchard analysis is shown in Fig. S9. An internalization assay using $\mathrm{NaN}_{3}$, KF (metabolic energy inhibitors), and $p$-tosyl-arginine methyl ester (peptidase inhibitor) was conducted as previously described [12].

\section{Steady-State Saturation Binding with Fluorescent-Based Detector $\left[\right.$ Arg $^{6}{ }^{6}$ D-Ala $\left.{ }^{9}\right] \alpha$-Factor-Edan (Fig. S8)}

Cells were grown and harvested as described above with the following changes. Cell stock suspension $(1 \mathrm{ml})$ at a concentration of $1 \times 10^{8}$ cells $/ \mathrm{ml}$ was dispensed into eight test tubes with a volume of $1.5 \mathrm{ml}$. Next, $50 \mu \mathrm{l}$ of cycloheximide $(10 \mathrm{mM})$ was added to each test tube, followed by incubation for $30 \mathrm{~min}$ and washing at 8,000 rpm for $10 \mathrm{~min}$. Various amounts of $\left[\mathrm{Arg}^{6}, \mathrm{D}-\right.$ 
A

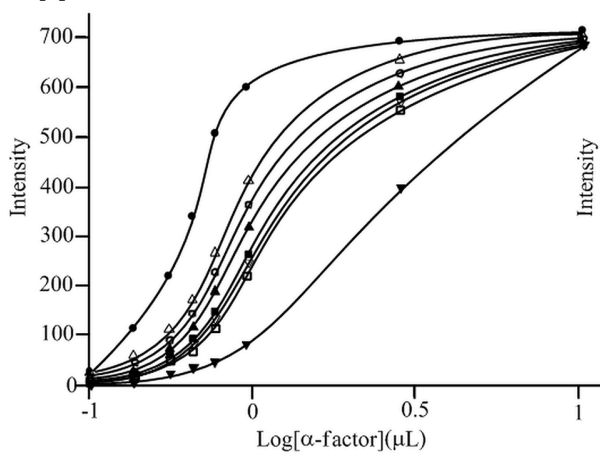

B

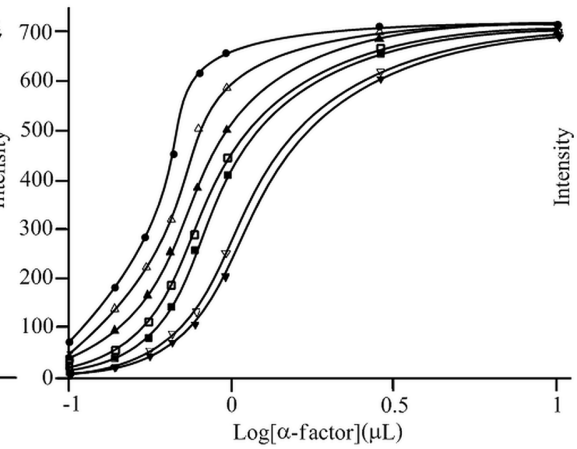

\section{C}

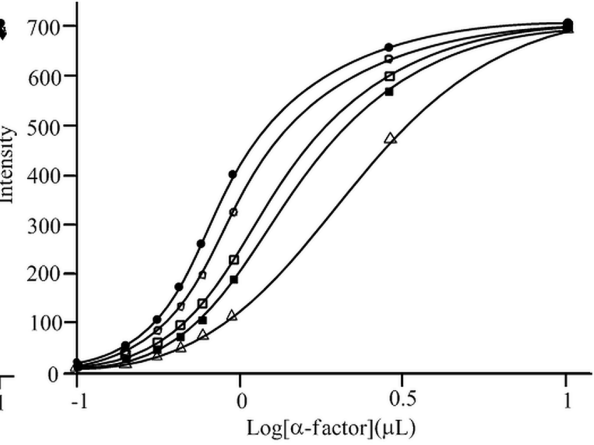

Fig. 1. FUS1-lacZ gene induction assay with FDG. Cells were treated with 0.1-10 $\mu$ l of analogs for $30 \mathrm{~min}$.

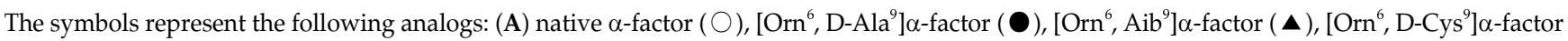

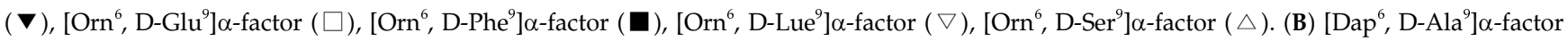

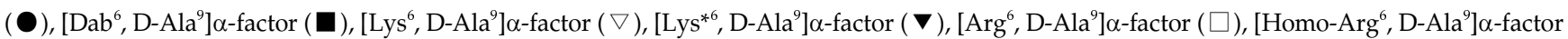
$(\triangle),\left[\mathrm{Glu}^{6}, \mathrm{D}-\mathrm{Ala}^{9}\right] \alpha$-factor $(\mathbf{\Delta}) .(\mathrm{C})\left[\mathrm{Orn}^{5}, \operatorname{Arg}^{6}, \mathrm{D}-\mathrm{Ala}^{9}\right] \alpha$-factor $(\boldsymbol{\square}),\left[\mathrm{Glu}^{5}, \operatorname{Arg}^{6}, \mathrm{D}-\mathrm{Ala}^{9}\right] \alpha$-factor $(\boldsymbol{O}),\left[\mathrm{Glu}^{5}, \operatorname{Orn}^{6}, \mathrm{D}-\mathrm{Ala}^{9}\right] \alpha$-factor $(\bigcirc),\left[\mathrm{Asp}^{5}\right.$, $\left.\operatorname{Orn}^{6}, \mathrm{D}^{-A l a}{ }^{9}\right] \alpha$-factor $(\square),\left[\operatorname{Arg}^{5,6}\right.$, D-Ala $\left.^{9}\right] \alpha$-factor $(\triangle)$.

Ala $\left.{ }^{9}\right] \alpha$-factor-Edan $\left[0.1 \mu \mathrm{l}\left(4.32 \times 10^{-10} \mathrm{~mol}, 4.32 \times 10^{-7} \mathrm{M}\right), 0.3 \mu \mathrm{l}\right.$ $\left(1.30 \times 10^{-9} \mathrm{~mol}, 1.30 \times 10^{-6} \mathrm{M}\right), 0.5 \mu \mathrm{l}\left(2.16 \times 10^{-9} \mathrm{~mol}, 2.16 \times 10^{-6} \mathrm{M}\right)$, $0.7 \mu \mathrm{l}\left(3.03 \times 10^{-9} \mathrm{~mol}, 3.03 \times 10^{-6} \mathrm{M}\right), 1 \mu \mathrm{l}\left(4.32 \times 10^{-9} \mathrm{~mol}, 4.32 \times 10^{-6} \mathrm{M}\right)$, $1.3 \mu \mathrm{l}\left(5.62 \times 10^{-9} \mathrm{~mol}, 5.62 \times 10^{-6} \mathrm{M}\right)$, and $1.5 \mu \mathrm{l}\left(6.48 \times 10^{-9} \mathrm{~mol}\right.$, $\left.\left.6.48 \times 10^{-6} \mathrm{M}\right)\right]$ at $4.32 \times 10^{-3} \mathrm{M}(1 \mathrm{mg}$ of detector $/ 110 \mu \mathrm{l}$ of saline water) were added to each test tube. Saline water was then added to give a final volume of $1 \mathrm{ml}$. Initiation of binding was processed with continuous vortexing (2,000 rpm) on a Finemixer Mx 2 (Finepcr, Korea) at $4^{\circ} \mathrm{C}$. After $30 \mathrm{~min}$, all test tubes were centrifuged for $10 \mathrm{~min}$ at $8,000 \mathrm{rpm}$, after which supernatant (about $1 \mathrm{ml}$ ) was filtered through $0.2 \mu \mathrm{m}$ Acrodisc LC syringe filters. Portions $(1 \mathrm{ml})$ of filtrates were dispensed into a cuvette $(1 \mathrm{~cm}$ path length), after which fluorescence intensity was measured at $430 \mathrm{~nm}$ with a fluorophotometer to determine the concentration of bound detector for each experimental portion.

\section{Competitive Binding of Nonchromogenic Competitors by Absorption Method}

Competition for bound detectors, $\left[\mathrm{Orn}^{6}\right] \alpha$-factor-[Cys $]_{3}$, against nonchromogenic competitive peptides was measured by the previous protocol [13]. $\mathrm{K}_{\mathrm{D}}$ values were calculated by dividing the experimentally determined concentration providing $50 \%$ binding displacement by $\left[1+\mathrm{H}_{\mathrm{T}} / \mathrm{K}_{\mathrm{D}}\right]$, where $\mathrm{Ht}=$ concentration of the detector and $\mathrm{K}_{\mathrm{D}}$ = dissociation constant of the detector (Figs. 2 and 3) [24].

\section{Competitive Binding of Nonchromogenic Competitors by Fluorescence Method}

Cells were grown and harvested as described above with the following changes. The cell stock suspension $(1 \mathrm{ml})$ at a concentration of $1 \times 10^{8} \mathrm{cell} / \mathrm{ml}$ was dispensed into eight test tubes, each with a volume of $1.5 \mathrm{ml}$. Next, $50 \mu \mathrm{l}$ of cycloheximide $(10 \mathrm{mM})$ was added to each test tube, followed by incubation for $30 \mathrm{~min}$ and washing at $8,000 \mathrm{rpm}$ for $10 \mathrm{~min}$. Next, $1 \mu \mathrm{l}$ of [ $\left.\mathrm{Arg}^{6}, \mathrm{D}-\mathrm{Ala}^{9}\right] \alpha$-factor-Edan at $3.75 \times 10^{-3} \mathrm{M}(1 \mathrm{mg}$ of detector $/ 110 \mu \mathrm{l}$ of saline water $)$ and various amounts of competitors $[0,0.5,1,3,5,10$, and $15 \mu \mathrm{l}(3.96 \times$ $\left.10^{-3} \mathrm{M}\right)$ ] were added to each tube. Saline water was added to obtain a final volume of $1 \mathrm{ml}$. Initiation of binding was processed with continuous vortexing (2,000 rpm) on a Finemixer Mx 2 (Finepcr, Korea) at $4^{\circ} \mathrm{C}$. After $30 \mathrm{~min}$, all test tubes were centrifuged for $10 \mathrm{~min}$ at $8,000 \mathrm{rpm}$, and the supernatant (about $1 \mathrm{ml}$ ) was then filtered through $0.2 \mu \mathrm{m}$ Acrodisc LC syringe filters. Portions $(1 \mathrm{ml})$ of the filtrates were subsequently dispensed into a cuvette ( $1 \mathrm{~cm}$ path length), after which the fluorescence intensity was measured at $430 \mathrm{~nm}$ using a fluorophotometer to determine the concentration of bound detector for each experimental portion. The total bound concentration of bound detector was calculated based on the decrease in fluorescence after the binding process for 30 min (Figs. 2 and 3) [26].

\section{Growth Arrest (Halo) Assay}

The procedure followed the assay protocol previously described by Hong [13]. Relative activities of the different analogs were determined by comparing the amount of peptide causing formation of a $30 \mathrm{~mm}$ halo from the regression line (Fig. 4). Each assay for growth arrest, binding, and gene induction was carried out at least three times, and the mean values are presented in the Figures and Tables.

\section{Results}

\section{Synthesis and Characterization of Peptide Analogs}

All target analogs investigated in this paper were 


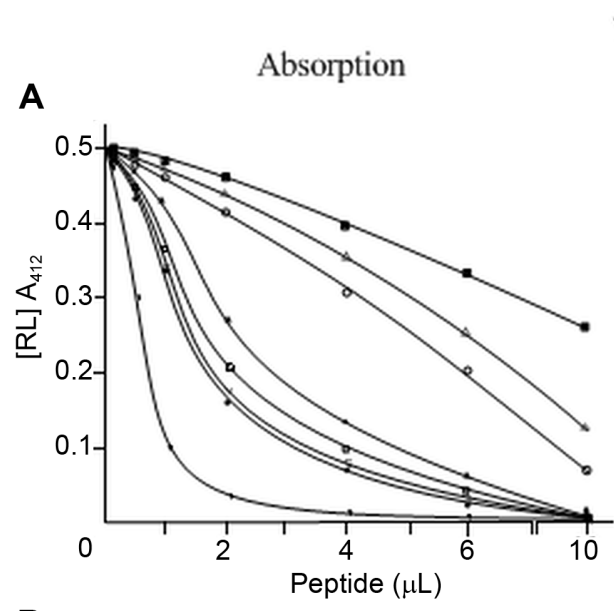

Y7925

B

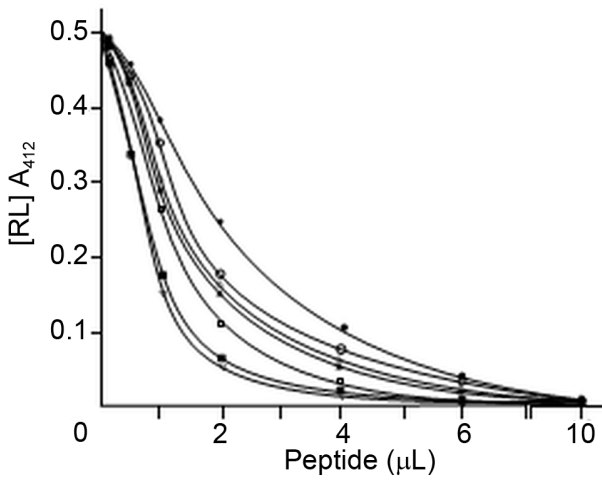

C

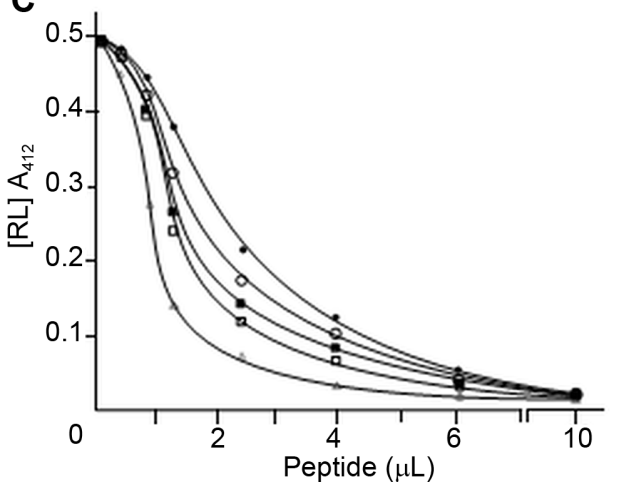

D

Fluorescence

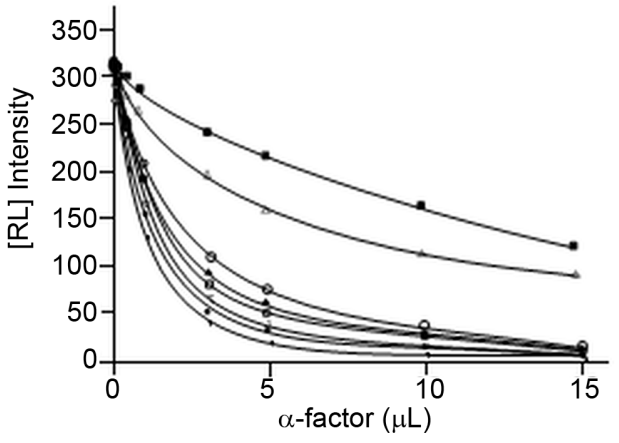

E

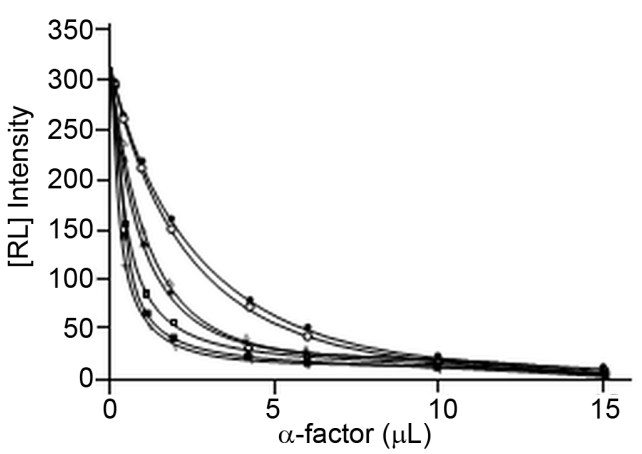

$\mathbf{F}$

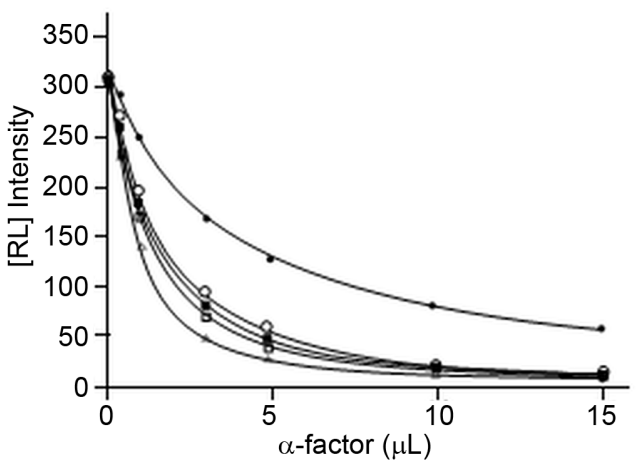

Fig. 2. Competition for binding of detectors $\left[\mathrm{Orn}^{6}\right] \alpha$-factor-[Cys $]_{3}$ and $\left[\mathrm{Arg}^{6}, \mathrm{D}-\mathrm{Ala}{ }^{9}\right] \alpha$-factor-Edan by synthetic analogs.

Detectors binding to $S$. cerevisiae $Y 7925$ (A-F) were performed in competition with synthetic analogs. The symbols represent the following competitors; (A and D) [Orn $\left.{ }^{6}, \mathrm{D}-\mathrm{Ala}{ }^{9}\right] \alpha$-factor $(\boldsymbol{\nabla})$, native $\alpha$-factor $(\boldsymbol{\bullet}),\left[\mathrm{Orn}^{6}, \mathrm{Aib}^{9}\right] \alpha$-factor $(\nabla),\left[\mathrm{Orn}^{6}, \mathrm{D}-\mathrm{Ser}^{9}\right] \alpha$-factor $(\square),\left[\mathrm{Orn}^{6}, \mathrm{D}\right.$-Glu $\left.{ }^{9}\right] \alpha$-factor

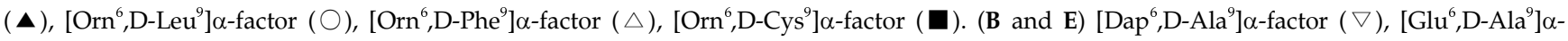

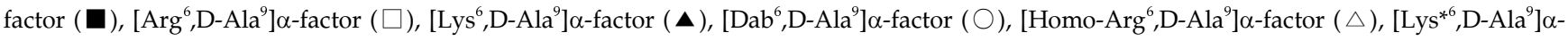

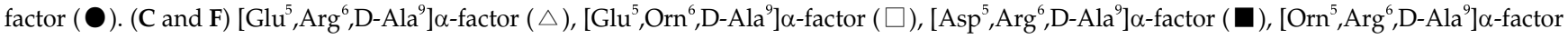
(O), $\left[\mathrm{Arg}^{5,6}, \mathrm{D}-\mathrm{Ala}{ }^{9}\right] \alpha-$-factor

efficiently synthesized on trityl resin using a solid phase approach [13]. In general, the crude products of TFA cleavage obtained from the resin contained approximately $85 \%$ to $95 \%$ of the major components, as indicated by analytical reversed-phase HPLC. Preparative HPLC purification yielded peptides with a homogeneity greater than $98 \%$, as determined by analytical HPLC using an acetonitrile/water/TFA gradient system. Molecular masses 


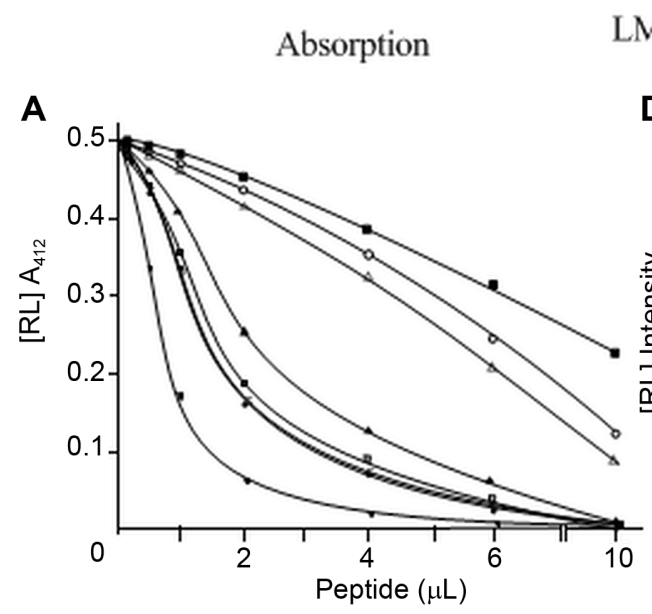

LM102

Fluorescence

D

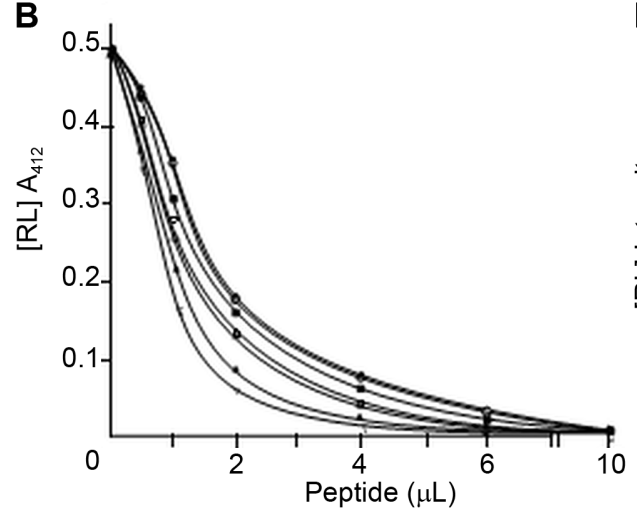

$E$
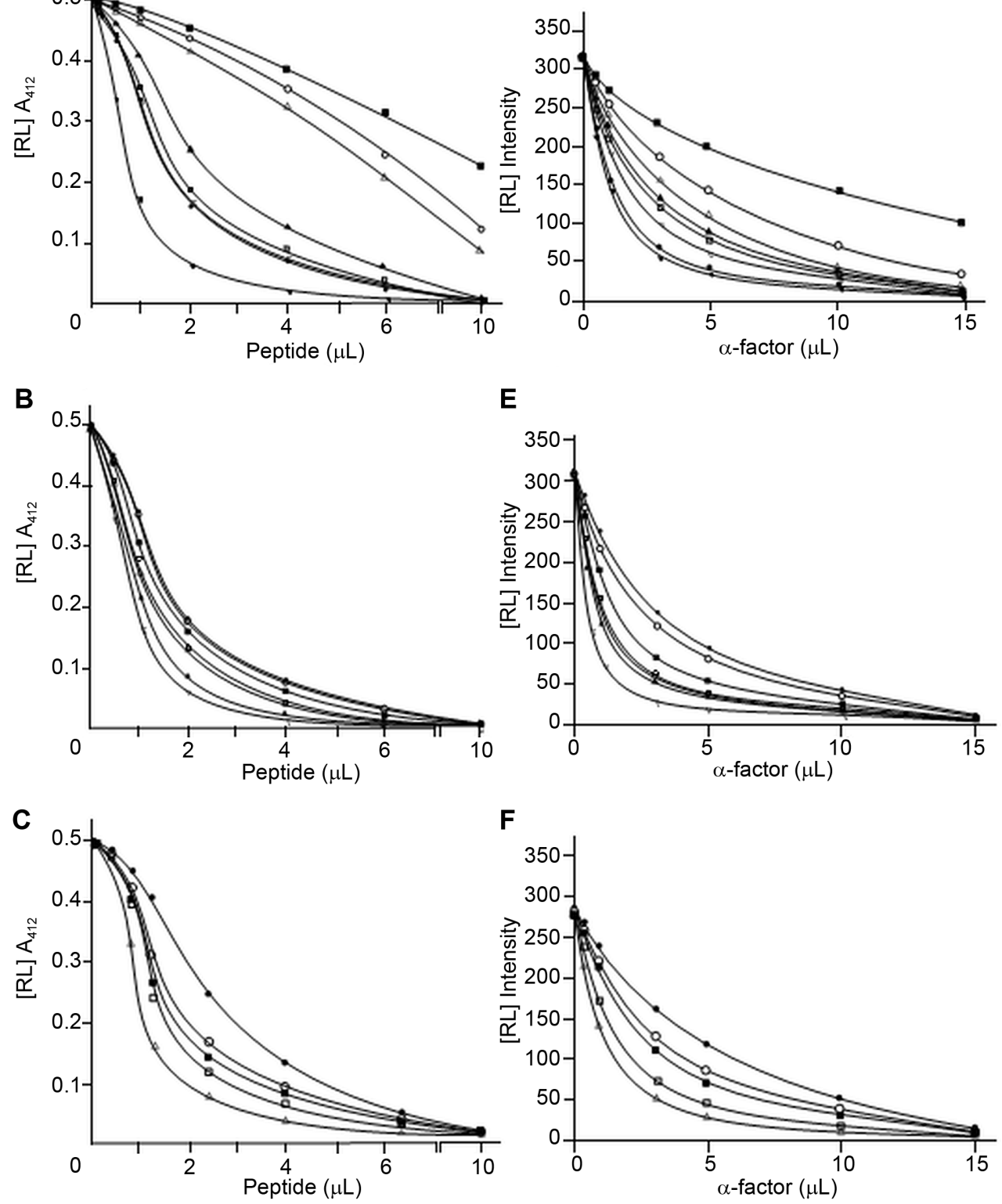

$\mathbf{F}$

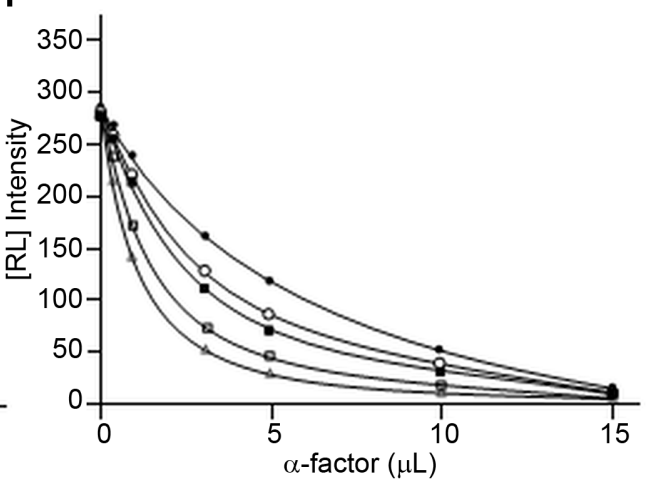

Fig. 3. Competition for binding of detectors $\left[\mathrm{Orn}^{6}\right] \alpha-$ factor- $[\mathrm{Cys}]_{3}$ and $\left[\mathrm{Arg}^{6}, \mathrm{D}-\mathrm{Ala}{ }^{9}\right] \alpha$-factor-Edan by synthetic analogs.

Detectors binding to S. cerevisiae LM102 (A-F) were performed in competition with synthetic analogs. The symbols represent the following competitors; (A and D) $\left[\mathrm{Orn}^{6}, \mathrm{D}-\mathrm{Ala}^{9}\right] \alpha$-factor $(\boldsymbol{\nabla})$, native $\alpha$-factor $(\mathbf{O}),\left[\mathrm{Orn}^{6}, \mathrm{Aib}^{9}\right] \alpha$-factor $(\nabla),\left[\mathrm{Orn}^{6}, \mathrm{D}-\mathrm{Ser}^{9}\right] \alpha$-factor $(\square),\left[\mathrm{Orn}{ }^{6}, \mathrm{D}-\mathrm{Glu}{ }^{9}\right] \alpha$-factor

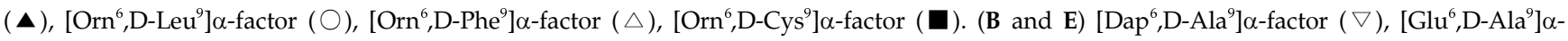
factor $(\mathbf{\Delta}),\left[\operatorname{Arg}^{6}, \mathrm{D}-\mathrm{Ala}{ }^{9}\right] \alpha$-factor $(\square)$, $\left[\mathrm{Lys}^{6}, \mathrm{D}-\mathrm{Ala}{ }^{9}\right] \alpha$-factor $(\bigcirc)$, [Dab $\left.{ }^{6}, \mathrm{D}-\mathrm{Ala}^{9}\right] \alpha$-factor $(\triangle)$, [Homo-Arg $\left.{ }^{6}, \mathrm{D}-\mathrm{Ala}{ }^{9}\right] \alpha$-factor $(\boldsymbol{\mathbf { Q }}),\left[\mathrm{Lys}^{* 6}, \mathrm{D}-\mathrm{Ala}{ }^{9}\right] \alpha-$ factor $(\mathbf{O})$. (c and f) $\left[\mathrm{Glu}^{5}, \mathrm{Arg}^{6}, \mathrm{D}-\mathrm{Ala}^{9}\right] \alpha$-factor $(\triangle),\left[\mathrm{Glu}^{5}, \mathrm{Orn}^{6}, \mathrm{D}-\mathrm{Ala}^{9}\right] \alpha$-factor $(\square),\left[\mathrm{Asp}^{5}, \mathrm{Arg}^{6}, \mathrm{D}-\mathrm{Ala}^{9}\right] \alpha$-factor $(\boldsymbol{\square}),\left[\mathrm{Orn}^{5}, \mathrm{Arg}^{6}, \mathrm{D}-\mathrm{Ala}^{9}\right] \alpha-$ factor (○), $\left[\mathrm{Arg}^{5,6}, \mathrm{D}-\mathrm{Ala}{ }^{9}\right] \alpha$-factor

of all final analogs and detector peptide, $\left[\mathrm{Arg}^{6}, \mathrm{D}-\mathrm{Ala}{ }^{9}\right] \alpha-$ factor-Edan, assessed by LC/MS were consistent with expected values within $1 \mathrm{Da}$ (Fig. S1 and Table S1).

\section{Expression of Ste2p in Yeast and Saturation Binding}

Expression of Ste2p was monitored using two approaches: SDS-page electrophoresis and detector binding to whole 
Y7925
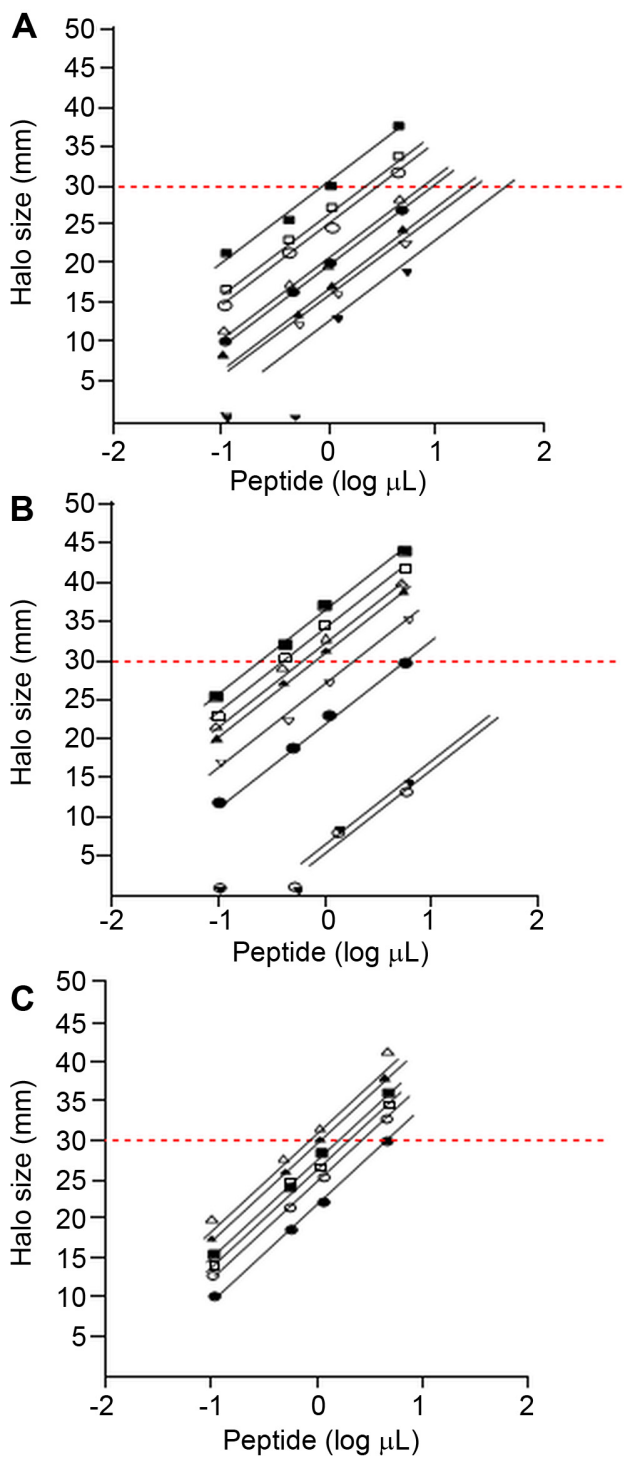

LM102
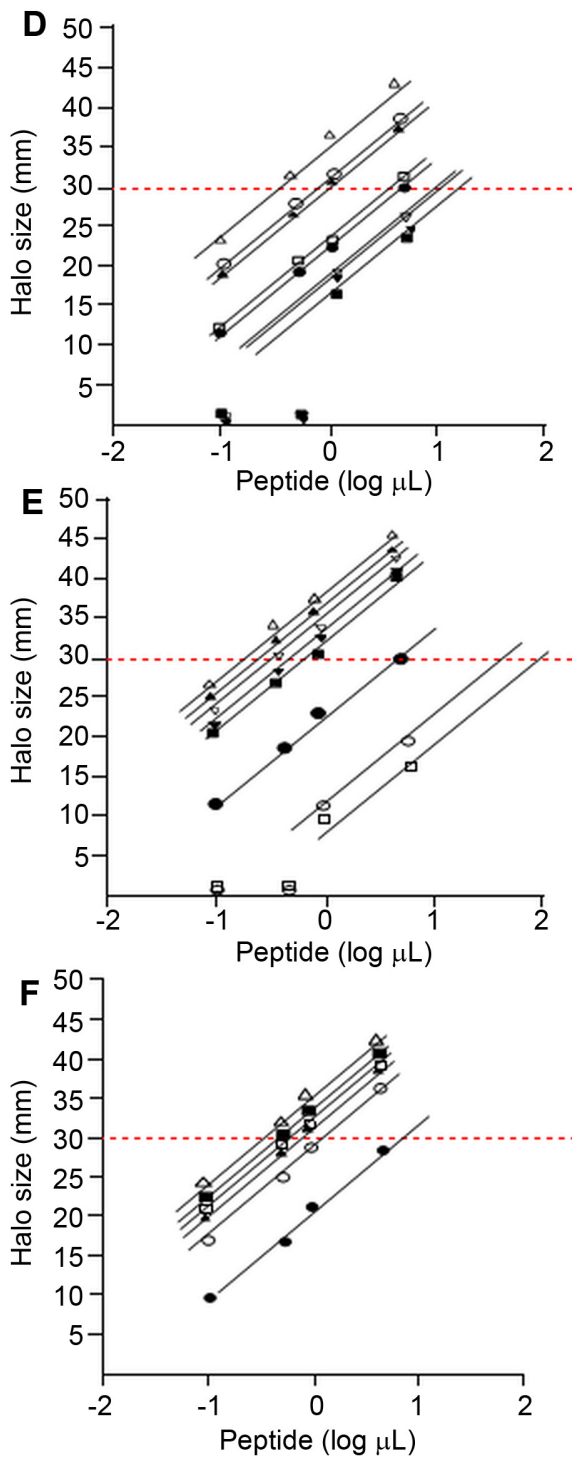

Fig. 4. Bioactivity of $\alpha$-factor analogs by halo assay in S. cerevisiae Y 7925 (a-c) and LM 102 (D-F).

(A) $\left[\mathrm{Orn}^{6}, \mathrm{D}-\mathrm{Ala}^{9}\right] \alpha$-factor $(\square)$, [Orn $\left.{ }^{6}, \mathrm{D}-\mathrm{Ser}^{9}\right] \alpha$-factor $(\mathbf{\square}),\left[\operatorname{Orn}^{6}\right.$-D-Leu $\left.{ }^{9}\right] \alpha$-factor $(\bigcirc)$, native $\alpha$-factor $(\mathbf{O})$, [Orn ${ }^{6}$-Glu $] \alpha$-factor $(\triangle)$, [Orn ${ }^{6}, \mathrm{D}$ -

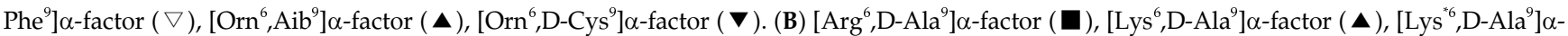

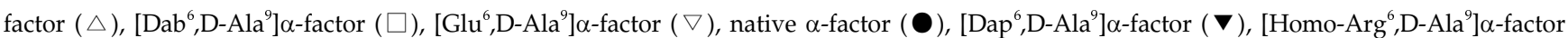
(O). (C) $\left[\mathrm{Glu}^{5}, \mathrm{Arg}^{6}, \mathrm{D}-\mathrm{Ala}^{9}\right] \alpha$-factor $(\triangle), \quad\left[\mathrm{Glu}^{5}, \mathrm{Orn}^{6}, \mathrm{D}-\mathrm{Ala}^{9}\right] \alpha$-factor $(\boldsymbol{\Delta}), \quad\left[\mathrm{Orn}^{5}, \mathrm{Arg}^{6}, \mathrm{D}-\mathrm{Ala}^{9}\right] \alpha-$ factor $\quad(\boldsymbol{\square}), \quad\left[\mathrm{Arg}^{5,6}, \mathrm{D}-\mathrm{Ala}^{9}\right] \alpha-\mathrm{factor}(\square)$, $\left[\mathrm{Asp}^{5}, \mathrm{Orn}^{6}, \mathrm{D}-\mathrm{Ala}^{9}\right] \alpha$-factor $(\bigcirc)$, native $\alpha$-factor $(\mathbf{O})$. (D) $\left[\mathrm{Orn}^{6}, \mathrm{D}\right.$-Ala $\left.{ }^{9}\right] \alpha$-factor $(\triangle)$, [Orn $\left.{ }^{6}, \mathrm{D}-\mathrm{Ser}^{9}\right] \alpha$-factor $(\bigcirc),\left[\mathrm{Orn}^{6}, \mathrm{D}\right.$-Leu $\left.{ }^{9}\right] \alpha$-factor $(\boldsymbol{\nabla}),\left[\mathrm{Orn}^{6}\right.$ Glu $\left.{ }^{9}\right] \alpha$-factor $(\square)$, native $\alpha$-factor $(\mathbf{O}),\left[\operatorname{Orn}^{6}, \mathrm{D}-\mathrm{Phe}^{9}\right] \alpha$-factor $(\boldsymbol{\nabla}),\left[\operatorname{Orn}^{6}{ }^{6} \mathrm{Aib}^{9}\right] \alpha$-factor $(\nabla)$, [Orn ${ }^{6}, \mathrm{D}$-Cys $\left.{ }^{9}\right] \alpha$-factor $(\boldsymbol{\square})$. (E) $\left[\mathrm{Arg}^{6}, \mathrm{D}-\mathrm{Ala}^{9}\right] \alpha$-factor

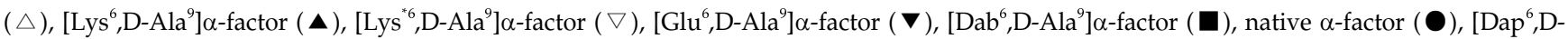

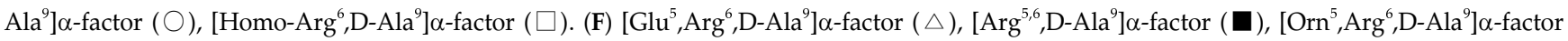
( $\square),\left[\mathrm{Glu}^{5}, \mathrm{Orn}^{6}, \mathrm{D}-\mathrm{Ala}{ }^{9}\right] \alpha$-factor $(\boldsymbol{\Delta}),\left[\mathrm{Asp}^{5}, \mathrm{Orn}^{6}, \mathrm{D}-\mathrm{Ala}^{9}\right] \alpha$-factor $(\bigcirc)$, native $\alpha$-factor $(\bullet)$.

cells. Fig. S4 shows the results of electrophoresis performed on cell lysates of strain LM102 without Ste2p (lane 3), strain LM102 with Ste2p (lane 2), and pure Ste2p isolated by Ni-
NTA affinity column chromatography (lane 4). In lanes 2 and 4 , a protein band with an apparent molecular weight of $47.5 \mathrm{kDa}$ was observed. This band was not visible in host 
strain LM102 (lane 3) containing the empty shuttle vector pESC-LEU. Expression of Ste2p was also assessed by western blotting using His-tag antibody. Immunoreactive Ste2p bands were observed in lanes 2 and 4 (Fig. S4).

Measurement of detector binding in whole cells is quantitative and has the advantage of detecting only active receptor molecules (Fig. S10). STE2 gene expression was monitored along with cell growth on selective media. Transformed strain LM102 containing a plasmid encoding STE2 gene was grown in liquid media containing $2 \%$ galactose, which is an inducer of STE2 gene expression. After cell growth, Ste2p receptor expression was determined by the steady-state saturation binding technique [13]. Since a given number of cells is expected to possess a finite number of receptors, saturation was assessed by examining binding as a function of increasing detector concentration using $2.5 \times 10^{11}$ cells (Fig. S8). The total concentration of bound detector was calculated based on the decrease in fluorescence after the binding process for $30 \mathrm{~min}$. As shown in Fig. S8, the number of binding sites per cell (dotted lines) in transformed LM102 was estimated to be $30 \%$ less than that of strain Y7925 (bold lines) based on a $30 \%$ reduction in saturation binding. Thus, the number of binding sites per cell for transformed LM102 was about 20,000 , as strain Y7925 is known to have 29,500 binding sites per cell [13].

\section{FUS1-lacZ Gene Induction Assay by Various Analogs}

S. cerevisiae LM102 carries the FUS1 gene, which is inducible by mating pheromones and is fused to the reporter gene $\beta$-galactosidase (lacZ). For quantitative in situ assay of enzyme activity, the substrate has to enter yeast cells. Therefore, we tested the rapid permeabilization of yeast cells employing three different detergents: SDS, chloroform, and digitonin (Fig. S5). Permeablization of S. cerevisiae LM102 cells was completed in $1 \mathrm{~h}$. Digitonin gave the most

Table 1. Biological activities of $\alpha$-factor analogs in halo assays and gene induction assays employing S. cerevisiae Y 7925 and LM102.

\begin{tabular}{|c|c|c|c|c|c|c|c|}
\hline \multirow{3}{*}{ No } & \multirow{3}{*}{ Peptide } & \multicolumn{4}{|c|}{ Halo assay } & \multirow{2}{*}{\multicolumn{2}{|c|}{$\begin{array}{c}\text { Gene induction assay } \\
\text { LM102 }\end{array}$}} \\
\hline & & \multicolumn{2}{|c|}{ Y 7925} & \multicolumn{2}{|c|}{ LM102 } & & \\
\hline & & $\begin{array}{c}\text { Halo }^{\mathrm{a}} \\
(\mu \mathrm{l} / 30 \mathrm{~mm})\end{array}$ & $\begin{array}{l}\text { Relative } \\
\text { activity }\end{array}$ & $\begin{array}{c}\text { Halo }^{\mathrm{a}} \\
(\mu \mathrm{l} / 30 \mathrm{~mm})\end{array}$ & $\begin{array}{l}\text { Relative } \\
\text { activity }\end{array}$ & $E C_{50}^{\mathrm{b}}(\mathrm{M})$ & $\begin{array}{c}\text { Relative } \\
\text { activity }\end{array}$ \\
\hline 1 & Native $\alpha$-factor & 10 & 100 & 5 & 100 & $6.25 \times 10^{-6}$ & 100 \\
\hline 2 & {$\left[\mathrm{Orn}^{6}, \mathrm{D}-\mathrm{Ala}^{9}\right] \alpha$-factor } & 0.66 & 1500 & 0.33 & 1500 & $4.37 \times 10^{-6}$ & 143 \\
\hline 3 & {$\left[\mathrm{Orn}^{6}, \mathrm{Aib}^{9}\right] \alpha$-factor } & 16.6 & 60 & 8.33 & 60 & $8.57 \times 10^{-6}$ & 60 \\
\hline 4 & {$\left[\mathrm{Orn}^{6}, \mathrm{D}-\mathrm{Cys}^{9}\right] \alpha$-factor } & 20 & 50 & 25 & 20 & $2.16 \times 10^{-5}$ & 31 \\
\hline 5 & {$\left[\mathrm{Orn}^{6}, \mathrm{D}-\mathrm{Glu}^{9}\right] \alpha$-factor } & 10 & 100 & 4.16 & 120 & $8.65 \times 10^{-6}$ & 58 \\
\hline 6 & {$\left[\mathrm{Orn}^{6}, \mathrm{D}-\mathrm{Phe}^{9}\right] \alpha$-factor } & 20 & 50 & 10 & 50 & $6.71 \times 10^{-6}$ & 51 \\
\hline 7 & {$\left[\mathrm{Orn}^{6}, \mathrm{D}-\mathrm{Lue}^{9}\right] \alpha$-factor } & 2 & 500 & 1.02 & 500 & $9.21 \times 10^{-6}$ & 45 \\
\hline 8 & {$\left[\mathrm{Orn}^{6}, \mathrm{D}-\mathrm{Ser}^{9}\right] \alpha$-factor } & 1.66 & 600 & 0.77 & 650 & $7.85 \times 10^{-6}$ & 70 \\
\hline 9 & {$\left[\mathrm{Dap}^{6}, \mathrm{D}-\mathrm{Ala}^{9}\right] \alpha$-factor } & 100 & 10 & 25 & 20 & $3.74 \times 10^{-6}$ & 167 \\
\hline 10 & {$\left[\mathrm{Dab}^{6}, \mathrm{D}-\mathrm{Ala}{ }^{9}\right] \alpha$-factor } & 0.71 & 1400 & 0.35 & 1400 & $7.05 \times 10^{-6}$ & 88 \\
\hline 11 & {$\left[\mathrm{Lys}^{6}, \mathrm{D}-\mathrm{Ala}{ }^{9}\right] \alpha$-factor } & 0.55 & 1800 & 0.27 & 1850 & $8.44 \times 10^{-6}$ & 62 \\
\hline 12 & {$\left[\mathrm{Lys}^{* 6}{ }^{* 6} \mathrm{D}-\mathrm{Ala}{ }^{9}\right] \alpha$-factor } & 0.62 & 1600 & 0.31 & 1600 & $9.50 \times 10^{-6}$ & 50 \\
\hline 13 & {$\left[\mathrm{Arg}^{6}, \mathrm{D}-\mathrm{Ala}^{9}\right] \alpha$-factor } & 0.51 & 1950 & 0.25 & 2000 & $6.42 \times 10^{-6}$ & 94 \\
\hline 14 & {$\left[\right.$ Homo-Arg $\left.^{6}, \mathrm{D}-\mathrm{Ala}^{9}\right] \alpha$-factor } & 100 & 10 & 50 & 10 & $5.16 \times 10^{-6}$ & 121 \\
\hline 15 & {$\left[\mathrm{Glu}^{6}, \mathrm{D}-\mathrm{Ala}{ }^{9}\right] \alpha$-factor } & 1.43 & 700 & 0.3 & 1500 & $6.01 \times 10^{-6}$ & 107 \\
\hline 16 & {$\left[\mathrm{Orn}^{5}, \mathrm{Arg}^{6}, \mathrm{D}-\mathrm{Ala}^{9}\right] \alpha-$ factor } & 1.11 & 900 & 0.41 & 1250 & $8.49 \times 10^{-6}$ & 62 \\
\hline 17 & {$\left[\mathrm{Glu}^{5}, \mathrm{Arg}^{6}, \mathrm{D}-\mathrm{Ala}^{9}\right] \alpha-$ factor } & 0.71 & 1400 & 0.32 & 1550 & $6.71 \times 10^{-6}$ & 92 \\
\hline 18 & {$\left[\mathrm{Glu}^{5}, \mathrm{Orn}^{6}, \mathrm{D}-\mathrm{Ala}^{9}\right] \alpha$-factor } & 0.83 & 1200 & 0.41 & 1200 & $7.24 \times 10^{-6}$ & 82 \\
\hline 19 & {$\left[\mathrm{Asp}^{5}, \mathrm{Orn}^{6}, \mathrm{D}-\mathrm{Ala}^{9}\right] \alpha$-factor } & 1.33 & 750 & 0.55 & 900 & $7.82 \times 10^{-6}$ & 70 \\
\hline 20 & {$\left[\mathrm{Arg}^{5,6}, \mathrm{D}-\mathrm{Ala}{ }^{9}\right] \alpha$-factor } & 1.25 & 800 & 0.38 & 1300 & $1.12 \times 10^{-5}$ & 41 \\
\hline
\end{tabular}

${ }^{a}$ Halo assay as measured by the growth arrest. For each peptide $\left(6 \times 10^{-3} \mathrm{M}\right), 0.01 \mu \mathrm{l}(0.1 \mu \mathrm{g})-10 \mu \mathrm{l}(100 \mu \mathrm{g})$ were spotted on discs which were placed on YEPD plates containing S. cerevisiae Y $7925\left(1.2 \times 10^{6}\right.$ cells $)$.

${ }^{\mathrm{b}} E C_{50}=$ the concentration of analogs for $50 \%$ activity. 
promising result, exhibiting an almost $40 \%$ increase in activity compared to the other two detergents and complete achievement of permeabilization within 30-40 $\mathrm{min}$ [27].

LacZ gene induction in the transformed LM102 cells caused by the 20 analogs was determined using FDG substrate. Data were plotted for FDG intensity as a function of increasing pheromone concentration. The assay resulted in sharp curves with slopes that were parallel to each other. One-half of the maximum response $\left(E C_{50}\right)$ from these curves was determined, and the relative concentration of analogs was calculated using the standard curve for FDG (Fig. S7). Gene induction results of all analogs are shown in Fig. 1, whereas their $E C_{50}$ values are given in Table 1 . The activity results are as follows: $31-70 \%$ for $\left[\mathrm{Orn}^{6}, \mathrm{X}^{9}\right] \alpha$-factor analogs 3-8, 50-167\% for $\left[X^{6}, D-A l a^{9}\right] \alpha-f a c t o r$ analogs 9-15, and $41-92 \%$ for $\left[X^{5}, X^{6}, D-A l a{ }^{9}\right] \alpha$-factor analogs $16-20$ compared with the activity of native $\alpha$-factor. All of the analogs except 9, 14, and $\mathbf{1 5}$ were less active than native $\alpha$-factor 1 . Among them, only analog 9 had slightly higher activity than control analog $\mathbf{2}$. The activity trend for gene induction was almost parallel to the binding affinities of both S. cerevisiae Y7925 and LM102 without exception.

\section{Competition for Detector Binding by Nonchromogenic Competitors}

Binding affinities of the nonchromogenic synthetic analogs to their cognate receptors in S. cerevisiae MATa cells (Y7925 and LM102) were determined by measuring competition between increasing concentrations of synthetic competitors and a constant concentration of detector. Two detectors, $\left[\mathrm{Orn}^{6}\right] \alpha$-factor-[Cys $]_{3}$ for absorption-based detection and $\left[\mathrm{Arg}^{6}, \mathrm{D}-\mathrm{Ala}^{9}\right] \alpha$-factor-Edan for fluorescence-based detection, were used to compare and verify exact $I C_{50}$ values (Figs. 2 and 3). The affinities of these competitors for their receptors are represented by $I C_{50}$ values, which indicate $50 \%$ specific ligand binding. Their $I C_{50}$ values are given in Table 2.

For all analogs, both fluorescence-based binding affinities

Table 2. Concentration for $50 \%$ binding $\left(I C_{50}\right)$ and binding dissociation constant $\left(\mathrm{K}_{\mathrm{D}}\right)$ for fluorescence- and absorption-based affinity in S. cerevisiae Y 7925 and LM 102.

\begin{tabular}{|c|c|c|c|c|c|c|c|c|c|}
\hline \multirow{3}{*}{ No } & \multirow{3}{*}{ Peptide } & \multicolumn{4}{|c|}{ Y 7925} & \multicolumn{4}{|c|}{ LM102 } \\
\hline & & \multicolumn{2}{|c|}{ Fluorescence } & \multicolumn{2}{|c|}{ Absorption } & \multicolumn{2}{|c|}{ Fluorescence } & \multicolumn{2}{|c|}{ Absorption } \\
\hline & & $I C_{50}{ }^{a}$ & R.A $A^{b}$ & $I C_{50}{ }^{a}$ & R.A $A^{b}$ & $I C_{50}^{\mathrm{a}}$ & R.A $A^{b}$ & $I C_{50}{ }^{a}$ & R.A ${ }^{b}$ \\
\hline 1 & Native $\alpha$-factor & $7.20 \times 10^{-6}$ & 100 & $6.47 \times 10^{-6}$ & 100 & $7.41 \times 10^{-6}$ & 100 & $7.05 \times 10^{-6}$ & 100 \\
\hline 2 & {$\left[\mathrm{Orn}^{6}, \mathrm{D}-\mathrm{Ala}^{9}\right] \alpha$-factor } & $3.01 \times 10^{-6}$ & 238 & $1.98 \times 10^{-6}$ & 327 & $3.53 \times 10^{-6}$ & 210 & $2.36 \times 10^{-6}$ & 298 \\
\hline 3 & {$\left[\mathrm{Orn}^{6}, \mathrm{Aib}^{9}\right] \alpha$-factor } & $9.67 \times 10^{-6}$ & 73 & $6.67 \times 10^{-6}$ & 97 & $1.13 \times 10^{-5}$ & 65 & $7.08 \times 10^{-6}$ & 100 \\
\hline 5 & {$\left[\mathrm{Orn}^{6}, \mathrm{D}-\mathrm{Glu}^{9}\right] \alpha$-factor } & $9.93 \times 10^{-6}$ & 70 & $1.29 \times 10^{-5}$ & 50 & $1.11 \times 10^{-6}$ & 60 & $1.26 \times 10^{-5}$ & 56 \\
\hline 6 & {$\left[\mathrm{Orn}^{6}, \mathrm{D}-\mathrm{Phe} \mathrm{e}^{9}\right] \alpha$-factor } & $1.43 \times 10^{-5}$ & 50 & $2.02 \times 10^{-5}$ & 32 & $1.38 \times 10^{-5}$ & 35 & $1.91 \times 10^{-5}$ & 37 \\
\hline 7 & {$\left[\mathrm{Orn}^{6}, \mathrm{D}-\mathrm{Lue}^{9}\right] \alpha$-factor } & $6.93 \times 10^{-5}$ & 14 & $1.75 \times 10^{-5}$ & 37 & $6.91 \times 10^{-5}$ & 15 & $2.35 \times 10^{-6}$ & 30 \\
\hline 8 & {$\left[\mathrm{Orn}^{6}, \mathrm{D}-\mathrm{Ser}^{9}\right] \alpha$-factor } & $7.41 \times 10^{-6}$ & 98 & $7.80 \times 10^{-6}$ & 83 & $8.75 \times 10^{-6}$ & 80 & $7.75 \times 10^{-6}$ & 91 \\
\hline 9 & {$\left[\mathrm{Dap}^{6}, \mathrm{D}-\mathrm{Ala}^{9}\right] \alpha$-factor } & $3.00 \times 10^{-6}$ & 240 & $2.51 \times 10^{-6}$ & 258 & $3.30 \times 10^{-6}$ & 220 & $3.05 \times 10^{-6}$ & 231 \\
\hline 11 & {$\left[\right.$ Lys $\left.^{6}, \mathrm{D}-\mathrm{Ala}{ }^{9}\right] \alpha$-factor } & $1.41 \times 10^{-5}$ & 51 & $6.10 \times 10^{-6}$ & 106 & $1.44 \times 10^{-5}$ & 48 & $6.98 \times 10^{-6}$ & 101 \\
\hline 12 & {$\left[\right.$ Lys $\left.^{* 6}, \mathrm{D}-\mathrm{Ala}{ }^{9}\right] \alpha$-factor } & $1.74 \times 10^{-5}$ & 41 & $9.11 \times 10^{-6}$ & 71 & $1.74 \times 10^{-5}$ & 41 & $7.42 \times 10^{-6}$ & 95 \\
\hline 13 & {$\left[\mathrm{Arg}^{6}, \mathrm{D}-\mathrm{Ala}^{9}\right] \alpha$-factor } & $6.60 \times 10^{-6}$ & 109 & $5.35 \times 10^{-6}$ & 121 & $6.67 \times 10^{-6}$ & 101 & $6.46 \times 10^{-6}$ & 109 \\
\hline 14 & {$\left[\right.$ Homo-Arg $\left.^{6}, \mathrm{D}-\mathrm{Ala}^{9}\right] \alpha$-factor } & $4.50 \times 10^{-6}$ & 160 & $6.81 \times 10^{-6}$ & 95 & $4.57 \times 10^{-6}$ & 158 & $7.44 \times 10^{-6}$ & 105 \\
\hline 15 & {$\left[\mathrm{Glu}^{6}, \mathrm{D}-\mathrm{Ala}{ }^{9}\right] \alpha$-factor } & $6.00 \times 10^{-6}$ & 120 & $2.63 \times 10^{-6}$ & 246 & $6.53 \times 10^{-6}$ & 103 & $3.43 \times 10^{-6}$ & 205 \\
\hline 16 & {$\left[\mathrm{Orn}^{5}, \mathrm{Arg}^{6}, \mathrm{D}-\mathrm{Ala}^{9}\right] \alpha$-factor } & $9.63 \times 10^{-6}$ & 75 & $1.03 \times 10^{-5}$ & 63 & $1.11 \times 10^{-5}$ & 60 & $9.40 \times 10^{-6}$ & 75 \\
\hline 17 & {$\left[\mathrm{Glu}^{5}, \mathrm{Arg}^{6}, \mathrm{D}-\mathrm{Ala}{ }^{9}\right] \alpha$-factor } & $6.64 \times 10^{-6}$ & 102 & $4.14 \times 10^{-6}$ & 156 & $7.53 \times 10^{-6}$ & 103 & $4.76 \times 10^{-6}$ & 148 \\
\hline 18 & {$\left[\mathrm{Glu}^{5}, \mathrm{Orn}^{6}, \mathrm{D}-\mathrm{Ala}^{9}\right] \alpha$-factor } & $7.45 \times 10^{-6}$ & 97 & $6.83 \times 10^{-6}$ & 95 & $6.75 \times 10^{-6}$ & 95 & $7.50 \times 10^{-6}$ & 94 \\
\hline 19 & {$\left[\mathrm{Asp}^{5}, \mathrm{Orn}^{6}, \mathrm{D}-\mathrm{Ala}^{9}\right] \alpha$-factor } & $9.93 \times 10^{-6}$ & 70 & $7.80 \times 10^{-6}$ & 83 & $9.93 \times 10^{-6}$ & 70 & $8.49 \times 10^{-6}$ & 83 \\
\hline 20 & {$\left[\mathrm{Arg}^{5,6}, \mathrm{D}-\mathrm{Ala}^{9}\right] \alpha$-factor } & $1.94 \times 10^{-5}$ & 30 & $1.75 \times 10^{-5}$ & 37 & $1.94 \times 10^{-5}$ & 30 & $2.35 \times 10^{-5}$ & 30 \\
\hline
\end{tabular}

${ }^{\mathrm{a}} I C_{50}=$ the concentration of detector for $50 \%$ of the specific binding.

${ }^{\mathrm{b}} \mathrm{R} . \mathrm{A}=$ Relative Affinity 
and absorption-based binding affinities to their cognate receptors showed almost identical trends. Fluorescencebased binding affinities were similar to or slightly lower than absorption-based binding affinities in both strain Y7925 and strain LM102. Fluorescence-based affinity results for strain Y7925 were as follows: $3-98 \%$ for $\left[\mathrm{Orn}^{6}, \mathrm{X}^{9}\right] \alpha$-factor analogs 3-8, 41-248\% for [ $\left[\mathrm{X}^{6}, \mathrm{D}-\mathrm{Ala}^{9}\right] \alpha$-factor analogs 9-15, and $30-102 \%$ for $\left[X^{5}, X^{6}, D-A l a{ }^{9}\right] \alpha$-factor analogs 16-20 compared with that of native $\alpha$-factor. The fluorescencebased affinity results for strain LM102 were as follows: 1$80 \%$ for $\left[\mathrm{Orn}^{6}, \mathrm{X}^{9}\right] \alpha$-factor analogs 3-8, 41-220\% for $\left[\mathrm{X}^{6}, \mathrm{D}-\right.$ Ala $\left.{ }^{9}\right] \alpha$-factor analogs 9-15, and 30-103\% for $\left[X^{5}, X^{6}, D-A l a{ }^{9}\right] \alpha-$ factor analogs 16-20 compared with that of native $\alpha$-factor. The trends detected in the absorption-based affinity results were the same as those found in the fluorescence-based affinity results, with slight variation in numerical values. Analogs 9, 14, 15, and 17 were more active than native $\alpha$-factor 1 in both assays. Among them, only analog 9 exhibited slightly higher potency than control analog 2 in the fluorescence-based assay.

Relative sensitivity between fluorescence-based and absorption-based assays was calculated by comparing cell concentrations and minimum detector volumes used in both assays. For the fluorescence-based assay, $1 \times 10^{8}$ cells $/ \mathrm{ml}$ were used, whereas $2.5 \times 10^{11}$ cells $/ \mathrm{ml}$ were used for the absorption-based assay, resulting in 2,500-fold higher cell counts for the absorption-based assay. In addition, the absorption-based assay [2.5 $\left.\mu \mathrm{l}\left(6.0 \times 10^{-3} \mathrm{M}\right)\right]$ required 5fold higher levels than the fluorescence-based assay [0.5 $\mu \mathrm{l}$ $\left.\left(3.75 \times 10^{-3} \mathrm{M}\right)\right]$ in terms of minimum volumes of detectors, indicating 5- to 10-fold higher sensitivity in the fluorescencebased assay. Therefore, the total ratio of sensitivity was about 12,500 , suggesting the fluorescence-based assay is highly sensitive.

\section{Steady-State Saturation Binding with Fluorescence-Based Detector}

The total concentration of bound detector was calculated based on the decrease in fluorescence after the binding process for $30 \mathrm{~min}$. To determine the level of non-specific binding, $\alpha$-cells were tested at the same concentrations using the same method. Total counts per minute bound to $\alpha$-cells were on average $10 \%$ of the total counts per minute bound to $\alpha$-cells (Fig. S8).

\section{Growth Arrest (Halo) Assay}

$\alpha$-Factor and its analogs arrested the growth of cells, and bioactive analogs presented clear zones around the disk (Fig. 5). Increasing amounts of pheromone promoted growth

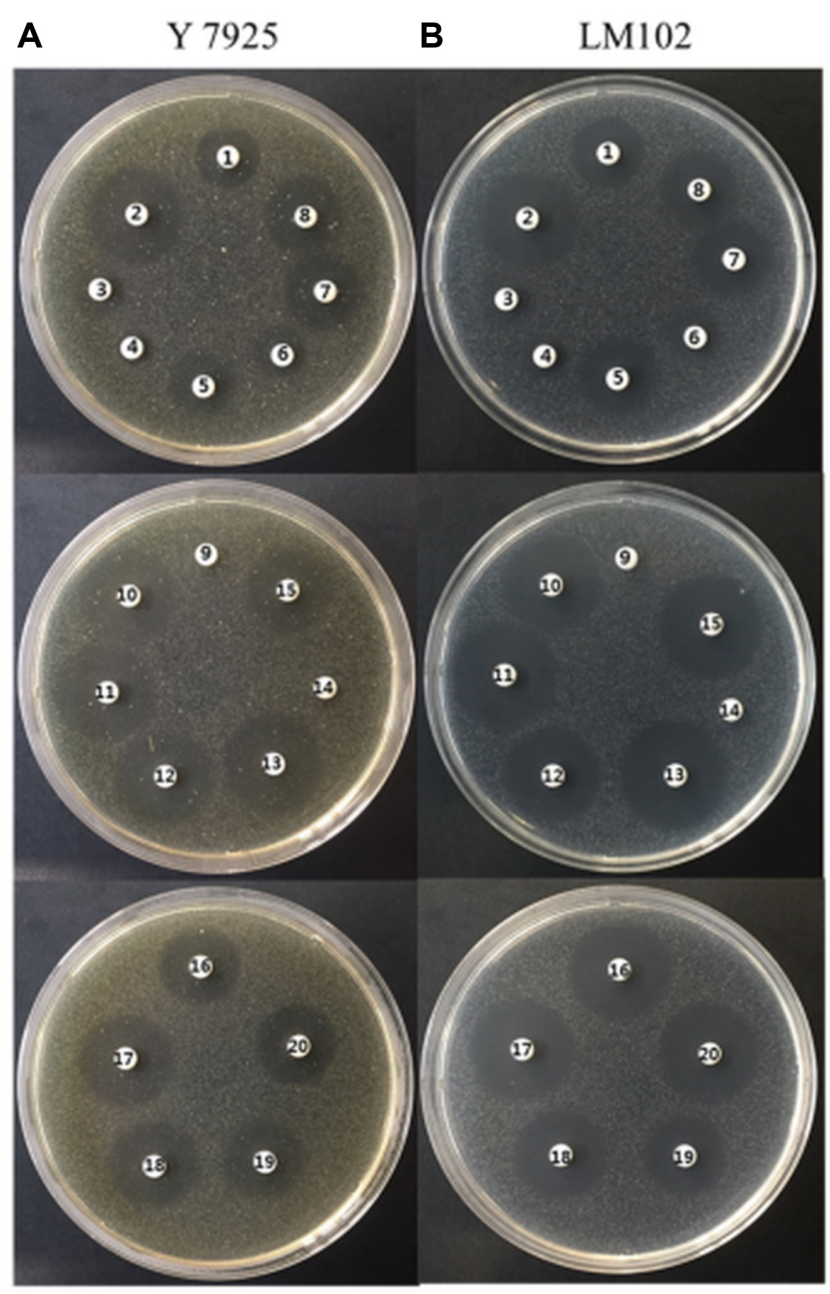

Fig. 5. Halo assays.

Halo assays employing S. cerevisiae Y 7925 and LM102 with synthetic analogs 1-20. Synthetic analogs $\left(1 \mu \mathrm{l}, 6 \times 10^{-3} \mathrm{M}\right)$ were placed on the disk at the center of the growth arrest, as shown by a halo of nongrowth in the lawn of strains S. cerevisiae Y 7925 (A) and LM102 (B). Analogs; 1) native $\alpha$-factor, 2) [Orn $\left.{ }^{6}, \mathrm{D}-\mathrm{Ala}{ }^{9}\right] \alpha$-factor, 3) $\left[\mathrm{Orn}^{6}, \mathrm{Aib}^{9}\right] \alpha-$ factor, 4) $\left[\mathrm{Orn}^{6}, \mathrm{D}-\mathrm{Cys}^{9}\right] \alpha$-factor, 5) $\left[\mathrm{Orn}^{6}, \mathrm{D}-\mathrm{Glu}^{9}\right] \alpha$-factor, 6) [Orn ${ }^{6}, \mathrm{D}-$ $\left.\mathrm{Phe}^{9}\right] \alpha$-factor, 7) $\left[\mathrm{Orn}^{6}, \mathrm{D}-\mathrm{Leu}^{9}\right] \alpha$-factor, 8) $\left[\mathrm{Orn}^{6}, \mathrm{D}-\mathrm{Ser}^{9}\right] \alpha$-factor, 9) $\left[\mathrm{Dap}^{6}, \mathrm{D}-\mathrm{Ala}^{9}\right] \alpha$-factor, 10) $\left[\mathrm{Dab}^{6}, \mathrm{D}-\mathrm{Ala}{ }^{9}\right] \alpha$-factor, 11) $\left[\mathrm{Lys}^{6}, \mathrm{D}-\mathrm{Ala}^{9}\right] \alpha-$ factor, 12) [Lys $\left.{ }^{* 6}, \mathrm{D}-\mathrm{Ala}{ }^{9}\right] \alpha$-factor, 13) [ $\left.\mathrm{Arg}^{6}{ }^{6}, \mathrm{D}-\mathrm{Ala}{ }^{9}\right] \alpha$-factor, 14) [Homo$\left.\mathrm{Arg}^{6}, \mathrm{D}-\mathrm{Ala}^{9}\right] \alpha$-factor, 15) $\left[\mathrm{Glu}^{6}, \mathrm{D}-\mathrm{Ala}^{9}\right] \alpha$-factor, 16) $\left[\mathrm{Orn}^{5}, \mathrm{Arg}^{6}, \mathrm{D}-\mathrm{Ala}{ }^{9}\right] \alpha-$ factor, 17) $\left[\mathrm{Glu}^{5}, \mathrm{Arg}^{6}, \mathrm{D}-\mathrm{Ala}^{9}\right] \alpha$-factor, 18) $\left[\mathrm{Glu}^{5}, \mathrm{Orn}^{6}, \mathrm{D}-\mathrm{Ala}^{9}\right] \alpha$-factor, 19) $\left[\mathrm{Asp}^{5}, \mathrm{Orn}^{6}, \mathrm{D}-\mathrm{Ala}{ }^{9}\right] \alpha$-factor, 20) $\left[\mathrm{Arg}^{5,6}, \mathrm{D}-\mathrm{Ala}{ }^{9}\right] \alpha$-factor. ${ }^{*}=$ Methylation.

arrest, as measured by halo size. These data were plotted in a graph as halo size versus amount of pheromone added to cell lawn and then linearized by regression analysis (Fig. 4). To compare the relative activities of the different analogs, the amount of peptide causing a halo size of $30 \mathrm{~mm}$ was 
determined from the regression line. Relative halo activities of the analogs against strain Y7925 and strain LM102 are presented in Table 1.

The relative activity results for strain Y7925 were as follows: $50-600 \%$ for $\left[\mathrm{Orn}^{6}, \mathrm{X}^{9}\right] \alpha$-factor analogs 3-8, 10$1,950 \%$ for $\left[X^{6}, \mathrm{D}-\mathrm{Ala}{ }^{9}\right] \alpha$-factor analogs $\mathbf{9 - 1 5}$, and 750 $1,400 \%$ for $\left[\mathrm{X}^{5}, \mathrm{X}^{6}, \mathrm{D}-\mathrm{Ala}{ }^{9}\right] \alpha$-factor analogs $\mathbf{1 6}-\mathbf{2 0}$ compared with that of native $\alpha$-factor. The relative activity results for strain LM102 were as follows: $20-650 \%$ for $\left[\mathrm{Orn}^{6}, \mathrm{X}^{9}\right] \alpha$-factor analogs 3-8, 10-2,000\% for [ $\left.\mathrm{X}^{6}, \mathrm{D}-\mathrm{Ala}{ }^{9}\right] \alpha$-factor analogs 915 , and $900-1,550 \%$ for $\left[X^{5}, X^{6}, D-A l a{ }^{9}\right] \alpha$-factor analogs $16-20$ compared with that of native $\alpha$-factor. The trends detected in the halo results differed from those detected in both the affinity and gene induction assay results. In the affinity and gene induction assays, only one analog, $\left[\mathrm{Dap}^{6}, \mathrm{D}-\mathrm{Ala}{ }^{9}\right] \alpha-$ factor 9, exhibited higher activity than control analog 2, whereas all analogs except $\left[\mathrm{Orn}^{6}{ }^{6} \mathrm{D}-\mathrm{Ala}{ }^{9}\right] \alpha$-factor series 3-8 showed higher potencies than control analog 2 in the halo assay, exhibiting $1,600-2,000 \%$ of the activity of native $\alpha$-factor 1 . The most active analog was analog 13 , with about $2,000 \%$ halo activity compared with that of native $\alpha$-factor $(100 \%)$, whereas its activities in both the affinity test $(109 \%)$ and gene induction assays (94\%) were only about as active as native $\alpha$-factor $(100 \%)$. Interestingly, analog $\mathbf{9}$, which displayed the highest binding activity to Ste2p receptor (about $240 \%$ of the activity of native $\alpha$-factor 1 ) showed insignificant halo activity.

\section{Discussion}

\section{Expression of Ste2p in Strain LM102 and Internalization of GPCR}

Strain LM102, in which the STE2 gene encoding $\alpha$-factor receptor is deleted, was selected as a host cell for production of protein. Strain LM102 has the advantage of production of GPCR as it carries the bar 1 gene mutant allele, which inactivates the BAR 1 protease responsible for degrading $\alpha$-factor [14]. Here, we selected pESC-LEU vector for expression and functional analysis of eukaryotic genes in the yeast S. cerevisiae, as strain LM102 lacking the LEU2 gene contains a yeast-selectable LEU2 marker gene in the vector backbone. pESC-LEU vector also contains the yeast $2 \mu$ origin, which enables autonomous replication of the plasmid in S. cerevisiae. Considering all of these factors, we selected pESC-LEU yeast/bacterial shuttle vector for expression of the STE2 gene encoding Ste2p in S. cerevisiae LM102. The cDNA of the STE2 gene containing histidinetag produced by PCR was cloned into the $2^{\text {nd }}$ multiple cloning site of pESC-LEU vector (Fig. S2). The resulting
pESC-LEU-STE2 vector was amplified using E. coli DH5 $\alpha$ competent cells, which is a well-characterized system designed for facilitated plasmid production with high transformation efficiency (CFU/ $\left.\mu \mathrm{g}:>1 \times 10^{9}\right)$, as well as prevention of degradation (endA1 mutation) and multimerization of plasmid (recA mutation) [16]. After identification of the isolated STE2 gene by DNA electrophoresis (Fig. S3), the pESC-LEU-STE2 vector was transformed into strain LM102 for production of His-tagged GPCR. The expressed His-tagged GPCR purified by Ni-NTA affinity column chromatography (HisTrap Excel, GE Healthcare, Uppsala, Sweden) was confirmed by SDS-page electrophoresis, immunoblotting using His-tag antibody, and saturation binding with fluorescence-based detector $\left[\mathrm{Arg}^{6}, \mathrm{D}-\mathrm{Ala}{ }^{9}\right] \alpha-$ factor-Edan. A protein band with an apparent molecular weight of $47.5 \mathrm{kDa}$ was observed using SDS-page electrophoresis and immunoblot assay (Fig. S4), and saturation binding showed that the transformed LM102 contained about 20,000 binding sites per cell (Figs. S8 and S9, insert). In our future study, we expect that such a GPCR genecloning technique employing pESC-LEU-STE2 vector will constitute an important homologous receptor model for future investigations of the molecular basis of pheromoneGPCR interactions.

Regarding desensitization susceptibility to $\alpha$-factor, we examined variations in surface receptor sites caused by internalization with $\mathrm{NaN}_{3}, \mathrm{KF}$ (metabolic energy inhibitors), and cycloheximide (protein biosynthesis suppressor) (Figs. S8 and S9, Table S2) [28]. Strain LM102 internalized a detectable amount (about 10-15\%) of bound $\alpha$-factor upon treatment with $\alpha$-factor (Figs. S8 and S9: below $7 \mu \mathrm{l}$ ), whereas apparent receptor uptake was not observed for Y7925 upon exposure to metabolic inhibitors (dashed line in Figs. S8 and S9). Thus, strain LM102 was a predominant yeast species with a highly susceptible desensitization function mediated by $\alpha$-factor, and variations in receptor sites were dependent on the yeast species. The different responses might have different thresholds for the same signal, or physically distinct receptors may elicit different physiological responses to $\alpha$-factor. The failure to reduce receptor sites in response to metabolic inhibitors in strain Y7925 [MATa his3-532 trp1 gal2] was likely due to insensitivity to metabolic inhibitors caused by mutation, which resulted in a defective metabolic pathway associated with down-regulation. Regarding the total number of active receptor sites on the membrane surface, strain LM102 showed 30\% fewer sites than strain $\mathrm{Y} 7925\left(\mathrm{~B}_{\text {cell }}=\right.$ $20,020)$ (Fig. S9, insert), which is in good agreement with the number of active receptors per cell obtained in the 
saturation binding assay depending on cell concentrations $\left(B_{\text {cell }}=20,000\right)$ (Fig. S10). These results suggest that expression of yeast GPCR using a chromosome system elicits lower efficiency than the pESC-LEU plasmid production system, even though the two selected strains were of different genotype. It appears that strain LM102 has a threshold in eliciting a receptor internalization process in response to $\alpha$-factor, as the internalization process was stopped at a detector volume of $7 \mu \mathrm{l}$, after which no more internalization was observed (Fig. S9).

\section{Development of a Highly Active Fluorescence-Based Detector and Its Efficiency}

To understand the signaling process involving $\alpha$-factor pheromone, it is important to understand how $\alpha$-factor pheromone is associated with its cognate GPCR receptor. One approach is to incorporate fluorescent probes into $\alpha$-factor pheromone $[9,29]$. However, the large size and strong hydrophobic nature of fluorophores can significantly alter ligand affinity for receptors. To address this problem, a parent analog (bound ligand) with high potency must be developed considering that the fluorophore assembly leads to a loss of detector biological activity. This problem was solved by developing highly active parent analogs.

Our previous investigation of charged residues at position $6\left(\mathrm{Leu}^{6}\right)$ showed that incorporation of a positivelycharged residue such as Orn at position 6 generally increases biological activity (3-fold increased receptor affinity as well as 15-fold increased halo activity compared to those of native $\alpha$-factor), whereas incorporation of a negativelycharged residue such as Glu at the same position reduces halo activity by up to $50 \%$ and affinity by $25 \%$ compared to a positively-charged analog [12]. To expand on this finding, we further examined the positive charge effect at position 6 by replacing Orn (three-carbon side chain and amino group) with other positive residues such as Dap (one-carbon side chain and amino group), Dab (two-carbon side chain and amino group), Lys (four-carbon side chain and amino group), and Arg (four-carbon side chain and guanidine group) to identify analogs with stronger potencies than analog $2\left[\mathrm{Orn}^{6}, \mathrm{D}-\mathrm{Ala}^{9}\right] \alpha$-factor. As summarized in Table 1, the relative halo activities of analogs $\mathbf{2}$ and 10-11 (except analog 9, which had very weak activity) were all strong (14- to 18-fold higher activity than that of native $\alpha$-factor 1 ) when tested against strains Y7925 and LM102. Thus, it appears that a steric bulkiness of more than one carbon is required at the position 6 side chain. In addition, a onecarbon elongation displacing analog 13 (four-carbon side chain and guanidine) with analog 14 (five-carbon side chain and guanidine) caused a dramatic 18-fold drop in activity to complete loss of halo activity, suggesting that restriction of the binding pocket to accommodate a side chain of only 2-4 carbons triggered signal transduction for halo activity.

The presence of central residues Lys $^{7}-$ Pro $^{8}-\mathrm{Gly}^{9}-\mathrm{Gln}^{10}$ forming a type II $\beta$-turn has been verified in conformation studies as a major structural feature of biologically active pheromone [7, 11, 29, 31]. Among the many synthetic $\beta$-turn substituents involving the central region, [D-Ala ${ }^{9} \alpha$-factor was reported to have the highest activity (about 5.8-fold increased halo activity and 1.4-fold increased receptor affinity compared to those of native analog). [10] We recently reported that $\left[\mathrm{Orn}^{6}, \mathrm{D}-\mathrm{Ala}{ }^{9}\right] \alpha$-factor 2 had higher activities than $\left[\mathrm{D}-\mathrm{Ala}{ }^{9}\right] \alpha$-factor in both assays (15-fold increased halo activity and 3-fold increased receptor affinity compared to those of native $\alpha$-factor 1). [12] In this study, we attempted to further enhance the biological activity of analog 2 by substitution of D-Ala ${ }^{9}$ with other D-residues such as anionic (analog 5), hydrophilic (analogs 4 and 8), hydrophobic (analog 7), and aromatic (analog 6) as well as $\beta$-turn breaking residues (analog 3) [32]. The results obtained upon D-residue or Aib substitution provide additional information regarding the role of D-Ala ${ }^{9}$ at this position of the pheromone. The large drop (about 3- to 100-fold reduction) in both assays of the analogs with other Dresidues and Aib (analogs 2-8) indicates that the D-Ala side chain is an optimum contributor to both assays, suggesting a small hydrophobic pocket that can roughly accommodate a one-carbon hydrophobic side chain at position 9. This observation also supports the previous finding that a type II $\beta$-turn around Gly $^{9}$ is stabilized by D-Ala $[4,10]$. Namely, an optimal type II $\beta$-turn required for efficient triggering of G-protein-coupled activation is presumably destabilized by substitution with other D-residues, and D-Ala ${ }^{9}$ as a hinge provides the best structural stable conformation for optimal interactions with the receptor.

The high halo activity of analog 13 (20-fold greater than that of native analog 1 and 1.3-fold higher than that of control analog 2) encouraged us to place additional charged residues at position $5\left(\mathrm{Gln}^{5}\right)$. In both the $\left[\mathrm{X}^{5}, \mathrm{Arg}^{6}, \mathrm{D}-\mathrm{Ala}{ }^{9}\right] \alpha-$ factor (analogs 16, 17, and 20) and $\left[X^{5}, \mathrm{Orn}^{6}, \mathrm{D}\right.$-Ala $\left.{ }^{9}\right] \alpha$-factor (analogs 18 and 19) series, incorporation of positively- $\left(X^{5}=\right.$ Orn and Arg) and negatively- $\left(X^{5}=\right.$ Glu and Asp) charged residues at position 5 resulted in decreases (1.3- to 2.4-fold) in halo activities of strains Y7925 and LM102. All analogs except analog 19 (Asp ${ }^{5}$ substitution) showed fairly high halo activities (8- to 15-fold higher than that of native analog 1), regardless of any charge differences. Interestingly, only a 
$20-30 \%$ reduction in halo activities compared to their parent analogs 13 and 2 was observed upon $\mathrm{Glu}^{5}$ replacement (analogs 17 and 18), respectively, and only a 50\% reduction was observed upon $\mathrm{Asp}^{5}$ replacement (analog 19) with the lowest potency compared to parent analog 2 . This modest reduction emphasizes a marginal role for position 5 in triggering isomerization of the receptor to an active state, resulting in high bioactivity. Conformational analyses of active analogs of $\alpha$-factor revealed that the $\mathrm{N}$-terminal region, $\operatorname{Trp}^{1}-\mathrm{His}^{2}-\mathrm{Trp}^{3}-\mathrm{Leu}^{4}-\mathrm{Gln}^{5}-\mathrm{Leu}^{6}$, formed a stable $\alpha$-helix, which is deeply implicated in receptor signaling, leading to high agonist activity [2, 33, 34]. The modest reduction in activity with any charged replacements provides indirect evidence of the spatial orientation of the side chain of position 5, which is likely to protrude outward into the surrounding cell membrane surface or external aqueous surface of the cell from the surface of the helix bundle rather than inward toward the cognate receptor site directly upon binding of the ligand.

Competitive binding assay employing a fluorescence detector was performed to analyze the affinities of nonchromogenic $\alpha$-factor analogs (competitors) to their cognate receptors (Table 2). The typical hyperbolic competition curves presenting normal steepness and noncooperativity indicate the existence of only one receptor population in strain LM102, which is the same as strain Y7925 [13]. Regarding the trends in the overall activities of the analogs (1-20) (Tables 1 and 2), even though the data sets apparently lacked correlation in part to predict the overall yeast GPCR model, no significant difference was observed in growth arrest (Table 1), receptor affinity (Table 2), or gene induction (Table 1). In the amino group series (analogs 9-12), relative affinity and gene induction gradually decreased as the carbon number of the side chain at position 6 increased (highest potencies of analog 9), suggesting a gene induction-governing site located at the surface of the binding hole. There was a close correlation between receptor affinity and gene induction ( $\beta$-galactosidase assay) without exception, whereas slight dissociation was detected between receptor affinity and halo activity for a couple of analogs. For example, analog 9 showing both strong affinity (25-fold higher than that of native $\alpha$-factor 1 ) and gene induction (1.7-fold higher than that of native $\alpha$-factor 1) presented negligible activity in the halo assay (10-fold lower than that of native $\alpha$-factor 1 ). Analog 14 had comparable affinity to native $\alpha$-factor 1 in both receptor affinity and the gene induction assay but showed no apparent halo activity. This lack of relationship has been detected by many groups who claimed that it could be attributed to independent thresholds required to initiate the biological responses of growth inhibition (halo assay) versus affinity or gene induction (lacZ) [4, 35, 36]. Namely, two mating pathways for growth arrest (halo activity) and transcriptional activation of fused gene induction (galactosidase activity) are segregated and regulated in a different manner [37]. At the same time, two pathways, cell cycle arrest induced by Far1 (factor arrest) and cell fusion between two opposite haploid cells induced by STE12 (sterility protein), are also coordinately regulated by FUS3 (MAPK fusion protein), which is activated upon binding to the pheromone secreted by the opposite cell type. Thus, the incomplete halo activities observed with analogs 9 and 14 can most likely be attributed to insufficient phosphorylated activation of Far1 due to the weak stimulation generated by both analogs (9 and 14), as complete activation of Far1 mediated by full phosphorylation is critical for sufficient cell cycle arrest. It is conceivable that $\alpha$-factor influencing Far1 activity is a finely tuned modulation process in response to a variety of signals, including FUS3 and STE12, that functions in part as a Far1 transcription inducer [38]. Conversely, it is apparent that activation of STE12 required for fused gene induction is directly linked to binding of $\alpha$-factor to its receptor in a less complicated process. Our recent study of mutant $S$. cerevisiae receptor employing pESC-LEU-STE2 plasmid produced similar outcomes, supporting the result that trends in the receptor affinity of $\alpha$-factor analogs are closely correlated with the activity of fused gene induction in the $S$. cerevisiae mating process. Even though data sets were not statistically consistent, there were no large discrepancies in the overall activities of the analogs (1-20) for growth arrest, receptor affinity, or gene induction, with the exception of two analogs ( 9 and 14). This general trend supports the model that two mating pathways, cell cycle arrest and cell fusion, are coordinately regulated by FUS3 [39]. However, two analogs (9 and 14) conferred extremely low activities only in halo assays, suggesting a downstream split in the signaling pathway for cell cycle arrest as well as the presence of a deeply buried sensitive receptor region that promotes stimulation of the pathway for cell cycle arrest by charged interactions and accommodates only 2-4 carbons of the side chain at position 6 (analogs 10-13).

Based on our earlier report that $\alpha$-factor receptor has a restricted binding site that can accommodate up to two additional residues at the $\mathrm{C}$-terminus of tridecapeptide and that C-terminal extension with one amino acid residue results in only slight reduction in affinity to cognate receptor [12], we designed a fluorophore-based detector in 
which Edan fluorophore was attached to the C-terminus of standard analog $\mathbf{1 3}$ having equal affinity to that of native $\alpha$-factor 1 . The resulting detector showed only a $25 \%$ reduction in receptor affinity and a $28 \%$ reduction in gene induction assay compared to parent analog 13. In addition, this study showed that the relative sensitivity of fluorescence-based affinity assay using the Edan probe was about 12,500-fold higher than that of absorption-based assay [13]. Therefore, we clearly demonstrated that the Edan probe was highly effective (sensitivity and receptor affinity) in a receptor binding study using whole yeast cells. Conditions for the assay were also determined to maximize specific interactions of $\alpha$-factor analogs with their potential receptors as well as to permit comparison of the binding results elicited by the nonchromogenic $\alpha$-factor (Table 2). Our comparative study performed on one competitor with two different detectors (fluorescence-based and absorption-based) revealed that the two $K_{D}$ values were within the experimental error. Regarding binding affinity, the fluorescence-based detector displaying 50\% higher affinity than the absorption-based assay showed reduced experimental error, as more competitor was required to achieve the same response. This detector is practically applicable to the determination of receptor affinity, even for nonchromogenic $\alpha$-factor analogs with poor binding ability due to higher sensitivity. The assay principle presented here is also applicable to other types of receptors in cases in which no hazardous radioactive ligand probe used only in a restricted working area is available $[29,30]$.

In conclusion, we developed a potent, fluorescence-based detector to determine the binding affinities of $\alpha$-factor analogs to GPCR receptor in $S$. cerevisiae with high efficiency and sensitivity. We identified analogs presenting the highest activity in halo assay (analog 13), GPCR receptor affinity in S. cerevisiae (analog 9), and gene induction assay (analog 9) reported to date. We also constructed vector pESC-LEU-STE2 by cloning STE2 fragment into plasmid pESC-LEU to produce GPCR with strain LM102. We expect that such a GPCR gene-cloning technique will provide an important homologous receptor model enabling understanding of the molecular mechanism governing $\alpha$-factor-induced receptor activation as well as structural information about the conformational differences between receptor resting and activated states.

\section{Acknowledgments}

This study was supported by a Yeungnam University research grant in 2016 and National Research Foundation of Korea research grant in 2017. In addition, we are indebted to a recently deceased professor, Murray Goodman, at University of California, San Diego, for conducting much of the peptide work.

\section{Conflict of Interest}

The authors have no financial conflicts of interest to declare.

\section{References}

1. Dohlamn HG. 2002. G proteins and pheromone signaling. Annu. Rev. Physiol. 64: 129-152.

2. Schöneberg $T$, Schulz A, Biebermann $H$, Hermsdorf $T$, Rompler H, Sangkuhl K. 2004. Mutant G-protein-coupled receptors as a cause of human diseases. Pharmac. Ther. 104: 173-206.

3. Klabunde T, Hessler G. 2002. Drug design strategies for targeting G-protein-coupled receptors. Chembiochem 3: 928944.

4. Naider F, Becker JM. 2004. The alpha-factor mating pheromone of Saccharomyces cerevisiae: a model for studying the interaction of peptide hormones and G protein-coupled receptors. Peptides 25: 1441-1463.

5. Stotzler D, Duntze W. 1976. Isolation and characterization of four related peptides exhibiting alpha factor activity from Saccharomyces cerevisiae. Eur. J. Biochem. 65: 257-262.

6. Naider F, Becker JM. 1986. Structure-activity relationships of the yeast alpha-factor. CRC Crit. Rev. Biochem. 21: 225-248.

7. Garbow JR, Breslav M, Antohi O, Naider F. 1994. Conformational analysis of the Saccharomyces cerevisiae tridecapeptide mating pheromone by $13 \mathrm{C}, 15 \mathrm{~N}$ rotational-echo double resonance nuclear magnetic resonance spectroscopy. Biochemistry 33: 10094-10099.

8. Henry LK, Khare S, Son C, Babu VV, Naider F, Becker JM. 2002. Identification of a contact region between the tridecapeptide alpha-factor mating pheromone of Saccharomyces cerevisiae and its $\mathrm{G}$ protein-coupled receptor by photoaffinity labeling. Biochemistry 41: 6128-6139.

9. Ding FX, Lee BK, Hauser M, Davenport L, Becker JM, Naider F. 2001. Probing the binding domain of the Saccharomyces cerevisiae alpha-mating factor receptor with rluorescent ligands. Biochemistry 40: 1102-1108.

10. Abel MG, Zhang YL, Lu HF, Naider F, Becker JM. 1998. Structure-function analysis of the Saccharomyces cerevisiae tridecapeptide pheromone using alanine-scanned analogs. $J$. Pept. Res. 52: 95-106.

11. Gounarides JS, Broido MS, Becker JM, Naider F. 1993. Conformational analysis of [D-Ala9]alpha-factor and [LAla9]alpha-factor in solution and in the presence of lipid. 
Biochemistry 32: 908-917.

12. Ahn HJ, Hong EY, Jin DH, Hong NJ. 2014. Highly active analogs of $\alpha$-factor and their activities against Saccharomyces cerevisiae. Bull. Korean Chem. Soc. 35: 1365-1374.

13. Ahn HJ, Kim HJ, Jin DH, Hong NJ. 2015. Spectrophotometric determination of affinities of $\alpha$-factors for their $G$ proteincoupled receptors in Saccharomyces cerevisiae. Bull. Korean Chem. Soc. 36: 1885-1896.

14. Kim KM, Lee YH, Naider F, Uddin MS, Akal-Strader A, Hauser M, et al. 2012. Multiple regulatory roles of the carboxy terminus of Ste2p a yeast GPCR. Pharmacol. Res. 65: 31-40.

15. Hanahan D. 1983. Studies on transformation of Escherichia coli with plasmids. J. Mol. Biol. 166: 557-580.

16. Gietz RD, Schiestl RH. 2007. High-efficiency yeast transformation using the LiAc/SS carrier DNA/PEG method. Nat. Protoc. 2: 31-34.

17. Hong NJ. 2010. Structure-activity relationships of 13- and 14-membered cyclic partial retro-inverso pentapeptides related to enkephalin. Bull. Korean Chem. Soc. 31: 874-880.

18. Kim DH, Hong NJ. 2012. Activity profiles of linear, cyclic monomer and cyclic dimer of enkephalin. Bull. Korean Chem. Soc. 33: 261-269.

19. Li J, Wang S, VanDusen WJ, Schultz LD, George HA, Herber WK, et al. 2000. Green fluorescent protein in Saccharomyces cerevisiae: real-time studies of the GAL1 promoter. Biotechnol. Bioeng. 70: 187-196.

20. Taylor RG, Walker DC, McInnes RR. 1993. E. coli host strains significantly affect the quality of small scale plasmid DNA preparations used for sequencing. Nucleic Acids Res. 21: $1677-1678$.

21. Bimboim HC, Doly J. 1979. A rapid alkaline extraction procedure for screening recombinant plasmid DNA. Nucleic Acid Res. 7: 1513-1523.

22. Chrambach A, Rodbard D. 1971. Polyacrylamide gel electrophoresis. Science 172: 440-451.

23. Thibodeau SA, Fang R, Joung JK. 2004. High-throughput $\beta$-galactosidase assay for bacterial cell-based reporter systems. Biotechniques 36: 410-415.

24. Vidal-Aroca, Giannattasio M, Brunelli E, Vezzoli A, Plevani P, Muzi-Falconi M, et al. 2006. One-step high-throughput assay for quantitative detection of beta-galactosidase activity in intact gram-negative bacteria, yeast, and mammalian cells. Biotechniques 40: 433-434.

25. Plovins A, Alvarez AM, Ibanez M, Molina M, Nombela C. 1994. Use of fluorescein-di-beta-D-galactopyranoside (FDG) and C12-FDG as substrates for beta-galactosidase detection by flow cytometry in animal, bacterial, and yeast cells. Appl. Environ. Microbiol. 60: 4638-4641.

26. Raths SK, Naider F, Becker JM. 1988. Peptide Analogues Compete with the Binding of $\alpha$-factor to Its Receptor in
Saccharomyces cerevisiae. J. Biol. Chem. 263: 17333-17341.

27. Kippert F. 1995. A rapid permeabilization procedure for accurate quantitative determination of $\beta$-galactosidase activity in yeast cells. FEMS Microbiol Lett. 128: 201-206.

28. Jenness DD, Sprtrick P. 1986. Down regulation of the $\alpha-$ factor pheromone receptor in S. cerevisiae. Cell 46: 345-353.

29. Mathew E, Bajaj A, Connelly SM, Sargsyan H, Ding FX, Hajduczok AJ, et al. 2011. Differential interactions of fluorescent agonists and antagonists with the yeast G protein coupled receptor Ste2p. J. Mol. Biol. 409: 513-528.

30. Son CD, Sargsyan H, Naider F, Becker JM. 2004. Identification of ligand binding regions of the Saccharomyces cerevisiae $\alpha$-factor pheromone receptor by photoaffinity cross-linking. Biochemistry 43: 13193-13203.

31. Xue CB, Mckinney A, Lu HF, Jiang Y, Becker JM, Naider F. 1996. Probing the functional conformation of the tridecapeptide mating pheromone of Saccharomyces cerevisiae through study of disulfide-constrained analogs. Int. J. Pept. Protein. Res. 47: 131-141.

32. Banerjee R, Chattopadhyay S, Basu G. 2009. Conformational preferences of a short Aib/Ala-based water-soluble peptide as a function of temperature. Proteins 76: 184-200.

33. Wakamatsu K, Okada A, Miyazawa T, Masui Y, Sakakibara S, Higashijima T. 1987. Conformations of yeast $\alpha$-mating factor and analog peptides as bound to phospholipid bilayer. Eur. J. Biochem. 163: 331-338.

34. Higashijima T, Masui Y, Chino N, Sakakibara S, Kita H, Miyazawa T. 1984. Conformations of tridecapeptide $\alpha$-mating factor from yeast Saccharomyces cerevisiae and analog peptides in aqueous solution. Eur. J. Biochem. 140: 163-171.

35. Marsh L. 1992. Substitutions in the hydrophobic core of the alpha-factor receptor of Saccharomyces cerevisiae permit response to Saccharomyces kluyveri alpha-factor and to antagonist. Mol. Cell. Biol. 12: 3959-3966.

36. Liu S, Henry LK, Lee BK, Becker JM, Naider F. 2000. Position 13 analogs of the tridecapeptide mating pheromone from Saccharomyces cerevisiae: design of an iodinatable ligand for receptor binding. J. Pept. Res. 56: 24-34.

37. Widmann C, Gibson S, Jarpe MB, Johnson GL. 1999. Mitogen-activated protein kinase: conservation of a threekinase module from yeast to human. Physiol. Rev. 79: 143-180.

38. Oehlen LJ, Mckinney JD, Cross FR. 1996. Ste12 and Mcm1 regulate cell cycle-dependent transcription of FAR1. Mol. Cell. Biol. 16: 2830-2837.

39. Bardwell L, Cook JG, Chang EC, Cairns BR, Thorner J. 1996. Signaling in the yeast pheromone response pathway: specific and high-affinity interaction of the mitogen-activated protein (MAP) kinases Kss1 and FUS3 with the upstream MAP kinase kinase Ste7. Mol. Cell. Biol. 16: 3637-3650. 